Ozone in Europe 2003

S. Solberg et al.

\title{
European surface ozone in the extreme summer 2003
}

S. Solberg ${ }^{1}$, P. Coddeville ${ }^{2}$, C. Forster ${ }^{1}$, Ø. Hov $^{3}$, Y. Orsolini ${ }^{1}$, and K. Uhse ${ }^{4}$

${ }^{1}$ Norwegian Institute for Air Research, Kjeller, Norway

${ }^{2}$ Ecole des Mines de Douai, France

${ }^{3}$ The Norwegian Meteorological Institute, Oslo, Norway

${ }^{4}$ Umweltbundesamt, Langen, Germany

Received: 6 July 2005 - Accepted: 22 August 2005 - Published: 20 September 2005

Correspondence to: S. Solberg (sverre.solberg@nilu.no)

(C) 2005 Author(s). This work is licensed under a Creative Commons License.

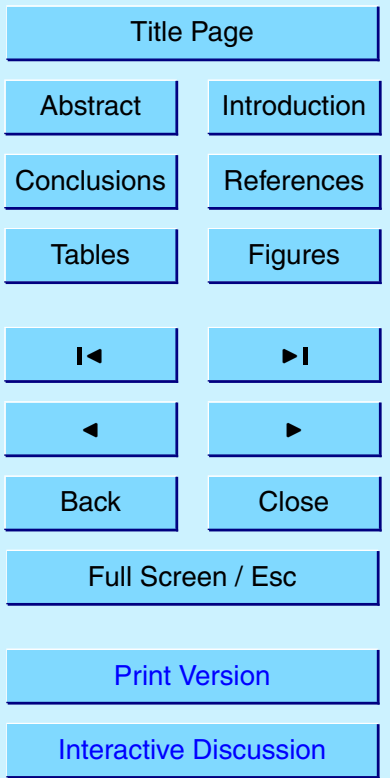

EGU 


\section{Abstract}

Measurements of ozone and other species from the European EMEP network in 2003 are presented. The European summer of 2003 was exceptionally warm and the surface ozone data for central Europe show the highest values since the end of the 1980s.

5 The concentrations were particularly high in June and August 2003. In this paper we argue that a number of positive feedback effects between the weather conditions and ozone contributed to the elevated surface ozone. Firstly, direct measurements of isoprene as well as the increased temperature and solar radiation indicate that biogenic emissions in Europe were increased during summer 2003 with a potential for enhanced ozone formation. Secondly, we show that the anticyclonic conditions during the ozone episodes were accompanied by an extended residence time of air parcels in the atmospheric boundary layer, a low total ozone column and a reduced cloud cover, all favouring ozone formation. Thirdly, based on the Lagrangian dispersion model FLEXPART, we show that is very likely that extensive forest fires on the Iberian Peninsula, 15 resulting from the drought and heat, contributed to the peak ozone values observed in North Europe in August. Additionally, forest fires in Siberia probably lead to an elevated background level of ozone and $\mathrm{CO}$ at northern latitudes during summer 2003 thereby increasing the level the peak ozone episodes sat on. Lastly, and most important, the heat wave presumably lead to less efficient ozone dry deposition due to stomata closure of the plants under drought stress. Due to climate change, situations like this may occur at a higher frequency in the future and may gradually overshadow the effect of reduced emissions from anthropogenic sources of $\mathrm{VOC}$ and $\mathrm{NO}_{\mathrm{x}}$. This scenario also holds for secondary PM.

\section{Introduction}

25 The European summer of 2003 was exceptionally warm, in particular in Central Europe. Based on a temperature reconstruction of monthly (back to 1659) and seasonal
ACPD

5, 9003-9038, 2005

Ozone in Europe 2003

S. Solberg et al.

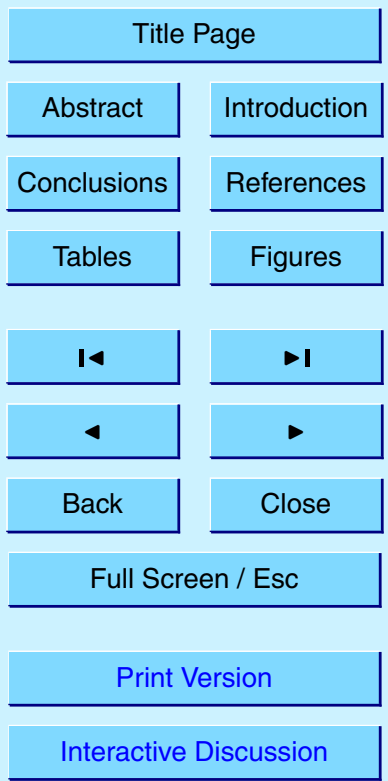

EGU 
(from 1500 to 1658 ) temperature fields for European land areas $\left(25^{\circ} \mathrm{W}\right.$ to $40^{\circ} \mathrm{E}, 35^{\circ} \mathrm{N}$ to $76^{\circ} \mathrm{N}$ ) Luterbacher et al. (2004) concluded that the summer of 2003 was very likely warmer than any other summer back to 1500 . Compared to the 1901-1995 average surface temperature, the summer of 2003 exceeded that average by about $2^{\circ} \mathrm{C}$ ( 4 standard deviations).

The observations reported within EEA (European Environment Agency) show exceptionally long-lasting and spatially extensive episodes of high ozone concentrations, mainly in the first half of August, and covering the regions with the highest temperatures (Fiala et al., 2003). For any monitoring site the average number of hourly ozone 10 exceedances above $180 \mu \mathrm{g} \mathrm{m}^{-3}$ was higher in the summer of 2003 than in any of the previous 12 years. Rural monitoring data from the EMEP (European Monitoring and Evaluation Program) network (Solberg et al., 2005) indicate that in central Europe an indicator like the 6-months AOT40 was higher in 2003 than in any other year since 1990, and that the AOT40 values in 2003 were almost a factor 2 higher than the average 15 during the 1990s. In Switzerland the 2003 summer mean of the daily ozone maxima exceeded the 1992-2002 summer mean of daily ozone maxima by more than $15 \mathrm{ppb}$, corresponding to 5 standard deviations of the 1992-2002 summer means, similar to the deviation in surface temperature (Ordonez et al., 2005).

The high levels of atmospheric pollutants had direct consequences for human health. 20 In case studies of the number of deaths related to the 2003 heat wave in the United Kingdom and the Netherlands, Stedman (2003) estimated that for the first two weeks of August 2003 there were 2045 excess deaths over the 1998-2002 average, and between 423 and 769 of these were related to elevated ambient ozone and $\mathrm{PM}_{10}$ concentrations. In a similar study for the Netherlands Fischer et al. (2003) found an excess of 1000-1400 deaths during the summer of 2003, and 400-600 were air pollution related (ozone and $\mathrm{PM}_{10}$ ). Trigo et al. (2005) have shown that in France the geographical pattern of the temperature anomaly matched particularly well the mortality rates.

Schär et al. (2004) and Beniston (2004) carried out regional climate simulation calculations to investigate if summers like the one in 2003 could become more prevalent in a
ACPD

5, 9003-9038, 2005

\section{Ozone in Europe 2003}

S. Solberg et al.

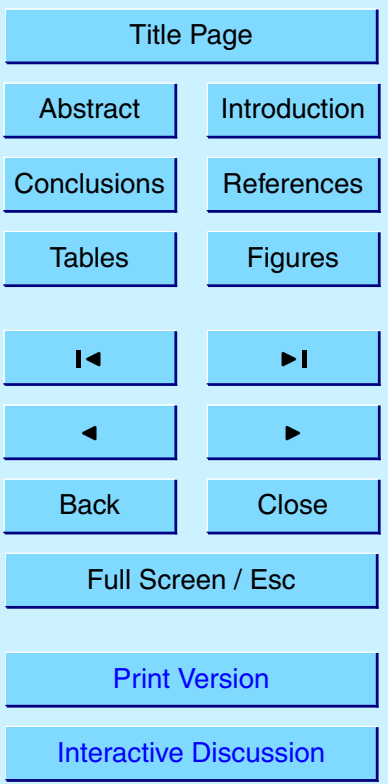

EGU 
greenhouse-gas scenario. Schär et al. (2004) found that in a greenhouse-gas scenario representing 2071-2100 conditions (SCEN) for a grid point in northern Switzerland for June-July-August (JJA) the JJA-average is shifted $4.6^{\circ} \mathrm{C}$ towards warmer temperatures, and there is a pronounced widening of its statistical distribution with the standard 5 deviation increasing by $102 \%$. This widening is highly significant. Schär et al. (2004) conclude that in response to greenhouse-gas forcing the year-to-year variability in European summer climate may increase, and that the unusual European summer of 2003 may be an example of what is to come. Beniston (2004) draws a similar conclusion: "For many purposes the 2003 event can be used as an analogue of future summers in 10 coming decades in climate impacts and policy studies".

In the following study we present surface ozone data from the EMEP network of rural background sites in Europe, as well as complementary measurements of isoprene and $\mathrm{CO}$ for 2003 and previous years. Ozone in the atmospheric boundary layer is controlled by the emissions of $\mathrm{NO}_{\mathrm{x}}$ and $\mathrm{VOC}$ and their photochemical transformations, the residence time of air parcels in the boundary layer over the source regions, the dry removal to the ground and the incoming UV and short-wave visible radiation. We show that the chemical ozone formation went up due to higher emissions of VOC and more UV and short-wave visible; the same air masses were exposed to high emissions longer and remained longer in the boundary layer than usual; and the removal mechanism declined.

\section{Meteorological conditions}

The meteorological conditions during the European summer 2003 have been extensively described in several recent studies, and we will only highlight some key points. Over Europe, persistent anticyclonic anomalies, warm temperatures and a series of
ACPD

5, 9003-9038, 2005

\section{Ozone in Europe 2003}

S. Solberg et al.

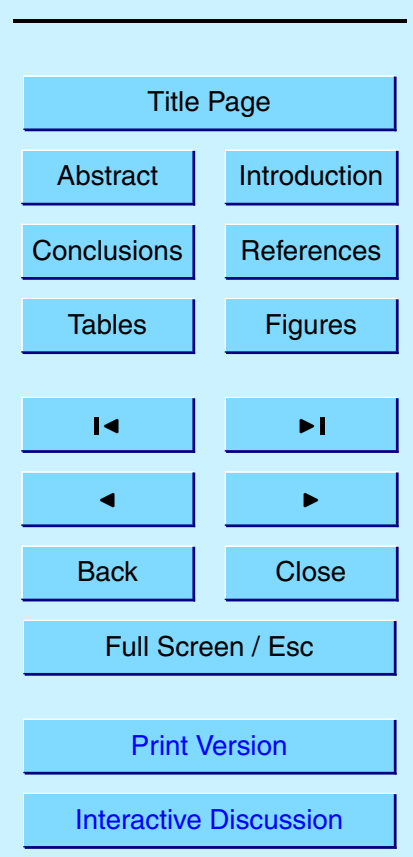

EGU In particular, several pronounced heat waves led to soaring ground temperatures in August. The hottest period was around the middle of August, during a highly anoma- 
lous blocking event centred over France (Grazzini et al., 2003; Black et al., 2004; Fink et al., 2004). All-time temperature records then tumbled over much of Europe. Schär et al. (2004) showed that the anticyclone over central Europe was four standard deviations above normal. The central Europe anticyclonic anomaly was part of an extensive, 5 quasi-stationary Rossby wave train, stretching from the western Atlantic across Europe and toward Siberia. These waves extended high into the stratosphere where they disturbed the easterly circumpolar circulation up to an altitude of $20-25 \mathrm{~km}$ (Orsolini and Nikulin, 2005).

In addition, the extreme surface temperatures gave the heat wave devastating im10 pact. These high temperatures resulted from a local radiative budget influenced by the lasting spring-to-summer dryness, by the low background soil moisture, and the clear skies during the anticyclonic conditions (Schär et al., 2004; Black et al., 2004). Another point worth mentioning is that the Atlantic jet stream was displaced northward, resulting in a reduction in the passage of cyclones over central Europe.

\section{Surface ozone}

Surface ozone measurements have been a part of the EMEP extended measurement activities since the third phase, and the monitoring started in the late 1980s (Hjellbrekke and Solberg, 2004). A total of 131 stations in 27 European countries reported data for 2003. The ozone monitoring sites are situated mainly in central, western and northern

20 Europe and the network density is poorer in the eastern and Mediterranean parts of Europe. The stations are located in rural or remote areas, away from local emission sources, and thus representative for the regional concentration field.

In most of the countries there are national or regional networks with a much larger number of ozone monitoring sites and the dedicated EMEP sites have been selected

weglan Institute for Air Research (NIU) based on the criterla of site location. The wegian Institute for Air Research (NILU) based on the criteria of site location. The monitoring data are subject to a strict quality control procedure as defined in the EMEP
ACPD

5, 9003-9038, 2005

Ozone in Europe 2003

S. Solberg et al.

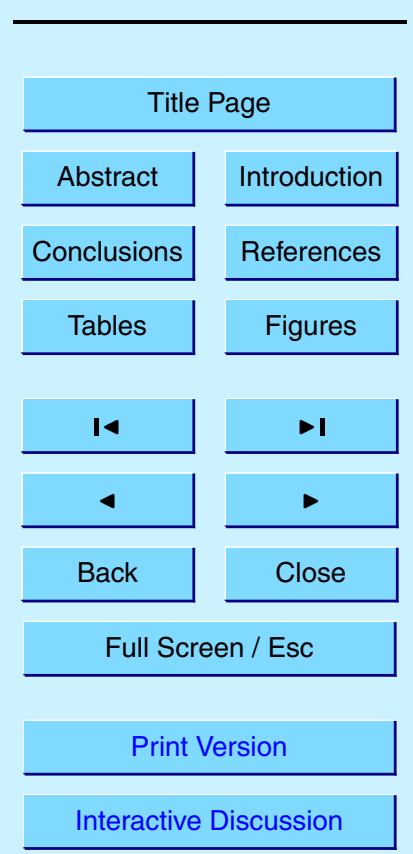

EGU 
manual (EMEP, 1996), both in the individual countries and at the EMEP-CCC, before being accepted as valid data. Information about the ozone data quality, calibration and maintenance procedures was collected from the participants during 2000 (Aas et al., 2001). The UV-absorption method was the only measurement method in use in 2003.

$5 \quad$ The annual maximum ozone concentrations observed in 2003 (as hourly values) are given in Fig. 1. Also given is the ratio of the 2003 maximum values relative to the maximum values observed during the period 1991-2002. Note that the number of years with ozone monitoring varies between the sites so that the ratios shown in Fig. 1 does not refer to the same group of previous years for all sites. The ratios were only 10 calculated for sites with ozone monitoring back to at least 1998. Figure 1 shows that the ozone concentrations in 2003 exceeded $220 \mu \mathrm{g} \mathrm{m}^{-3}$ over a large region in central Europe extending from Austria in southeast across most of Germany to Belgium, the Netherlands and the southeast part of the UK. The maximum values observed in 2003 exceeded the previous annual maximum values in France and at several sites 15 in Switzerland, Germany and Austria. Also in the most northern part of Scandinavia, record-breaking ozone values were observed in 2003. The high values in the far north were due to an episode of long-range transport from the European continent around 20 April peaking at $85 \mathrm{ppb}\left(170 \mu \mathrm{g} \mathrm{m}^{-3}\right)$ at Esange in northern Sweden.

In contrast, the 2003 peak values in UK were lower than the maximum values for

previous years except for Wicken Fen, and except for Harwell were the 2003 peak value reached the same peak value, $246 \mu \mathrm{g} \mathrm{m}^{-3}$, as observed during 1991-2002. The reason for these regional differences is both that the main area of the European ozone plume in 2003 was located south of UK and also that most of the UK sites have continuous monitoring data back to 1991 (and before) compared to e.g. the French sites which have a shorter monitoring history. It has been estimated that peak ozone concentrations at the EMEP stations in the UK declined about 30\% in the period 1986-1999 (NEGTAP, 2001). The main reason for this decline is believed to be the reduction in emissions of ozone precursors in Europe.

The ten highest ozone concentrations observed by the EMEP network in 2003 are
ACPD

5, 9003-9038, 2005

\section{Ozone in Europe 2003}

S. Solberg et al.

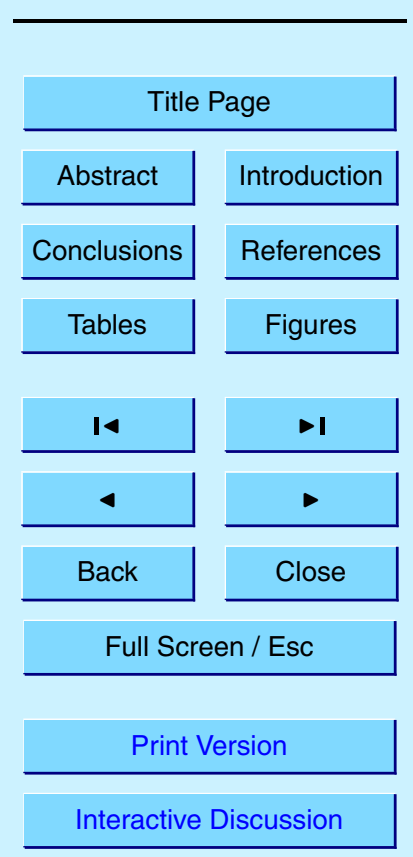

EGU 
given in Table 1. The highest value of $296 \mu \mathrm{g} \mathrm{m}^{-3}$ was observed at Eupen in Belgium. Most of the 10 highest peak values occurred during the first half of August with a few exceptions. At Montelibretti in the south the peak value occurred in June and in UK the peak value at Harwell was seen in mid July.

$5 \quad$ Figure 2 shows the monthly means of daily maximum (MDM) ozone values in 2003 for each of the months March-August relative to the highest MDMs during the years 1991-2002. The MDMs in June and particularly August were record-high compared to the data back to 1991 over a large region in central Europe. At Payern and Tänikon in Switzerland the MDM in August 2003 was approximately $15 \%$ higher than in any other August since 1991. However, the MDMs were also record-high in other periods of 2003, like in March and April in parts of Scandinavia and the UK. This shows that Europe in 2003 experienced record-high ozone concentrations in several individual periods during the whole spring/summer period. In May and July 2003 the MDMs in Central Europe and UK were lower than the maximum of the MDMs for previous years at most sites. In middle and northern Scandinavia, however, peak MDM values were observed in July.

As discussed by Fink et al. (2004), Europe experienced a series of heat waves in 2003, in which the August episode (1 to 13 August) was the most intense and the one that deviated most from the historical surface temperature records. During the heat 20 waves in June and August monthly temperature anomalies of $6-7^{\circ} \mathrm{C}$ were observed at sites in Switzerland and South Germany. At Hohenpeißenberg, Germany, the period June-August was $5^{\circ}$ higher than the average since 1781 when temperature monitoring began. The July temperatures were also higher than the temperature normal but in that month the anomalies were of the order of $1-3^{\circ} \mathrm{C}$. According to Fink et al. (2004)

the elevated temperatures in August were not accompanied by increased convection and vertical mixing. On the contrary the August heat wave lead to a stabilisation and subsidence, presumably due to the soil drought leading to low humidity in the lower troposphere.

As mentioned above, it is not surprising that the European heat waves were accom-
ACPD

5, 9003-9038, 2005

Ozone in Europe 2003

S. Solberg et al.

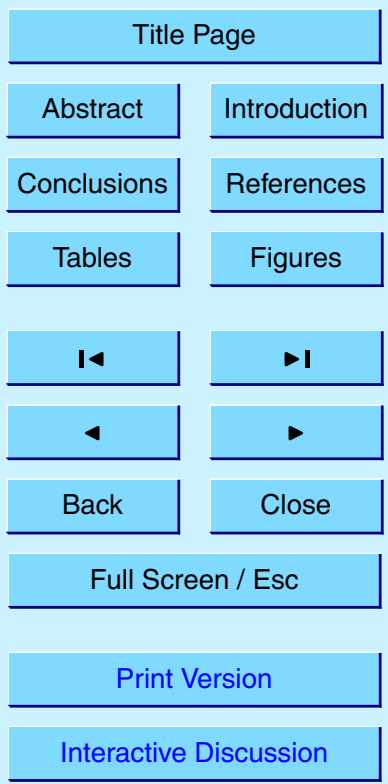

EGU 
panied by enhanced ozone concentrations. Increased UV radiation, less clouds and precipitation, extended residence time in the polluted boundary layer, increased biogenic emissions and drought all lead to higher ozone levels. Model calculations by Vautard et al. (2005) e.g. showed a better model performance when the model was run 5 with reduced dry deposition due to low soil moisture.

Not all meteorological perturbations experienced during heat-wave situations promote increased surface ozone concentrations, though. A low atmospheric humidity during the heat waves could suppress the ozone generation as the concentration of the $\mathrm{OH}$ radical is closely coupled to the absolute humidity of the atmosphere through 10 the reactions:

$\mathrm{O}_{3}+h v \rightarrow \mathrm{O}_{2}+\mathrm{O}^{\prime} \mathrm{D}$

$\mathrm{H}_{2} \mathrm{O}+\mathrm{O}^{\prime} \mathrm{D} \rightarrow 2 \mathrm{OH}$

which constitutes the main production channel of the $\mathrm{OH}$ radical in the troposphere. Although an ozone molecule is consumed in these reactions, a net ozone formation is 15 normally the result due to the importance of $\mathrm{OH}$ for driving the further photochemical reactions. The link between $\mathrm{OH}$ and net ozone formation is, however, not straight forward. Whereas $\mathrm{OH}$ is the main oxidation agent for the VOCs responsible for the ozone generation, $\mathrm{OH}$ also constitutes the main sink process of $\mathrm{NO}_{\mathrm{x}}$ through the reaction

$\mathrm{NO}_{2}+\mathrm{OH} \rightarrow \mathrm{HNO}_{3}$

20 The ozone peak values and maximum in MDM in June and August 2003 presented above should be considered keeping in mind that the emissions of European ozone precursors have been substantially reduced during the last 10-15 years. The annual emissions of $\mathrm{NO}_{\mathrm{x}}$ and $\mathrm{VOC}$ within the whole EMEP region have been reduced by $23 \%$ and $32 \%$, respectively during the period 1991-2002 (Vestreng, 2004), and the emission reductions in west and central Europe is larger than this. According to Vestreng (2004) the emission reduction of $\mathrm{NO}_{\mathrm{x}}$ in Germany and France during this period has been $43 \%$ and $31 \%$, respectively, and the reductions of VOC emissions have been even 9010
ACPD

$5,9003-9038,2005$

\section{Ozone in Europe 2003}

S. Solberg et al.

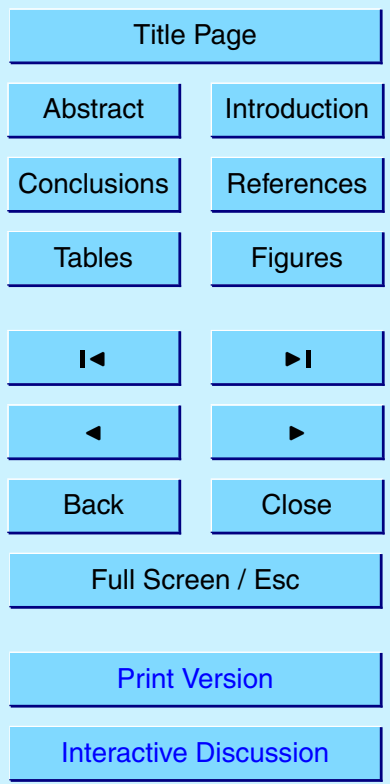

EGU 
larger. In spite of the substantial reduction in German $\mathrm{NO}_{\mathrm{x}}$ and $\mathrm{VOC}$ emissions the number of exceedances of the $180 \mu \mathrm{g} \mathrm{m}^{-3}$ was record-high in 2003 as seen by Fig. 3 (Umweltbundesamt, 2003).

ACPD

3.1. Regional ozone characteristics during 2003

5 To set the 2003 data in perspective, ozone measurements from the EMEP monitoring network during the 12-years period 1991-2002 was used as an ozone reference climatology. Several studies have, however, indicated a long-term increase in the background ozone concentration particularly in North Europe (Simmonds et al., 2004; Laurila et al., 2004) of the order of $0.3-0.5 \mathrm{ppbyr}^{-1}$. To take into account the effect of a long-term change from 1991 to 2002 a trend-adjusted reference climatology was calculated.

For each day $i$ in year $y$ the 30 days' running median $\hat{C}_{i, y}$ and running 10- and 90-percentiles were calculated based on daily ozone maximum values:

$\hat{C}_{i, y}=$ Median $\left(c_{j, y}\right), j=\left[i-\frac{\mathrm{n}}{2}, \ldots, i+\frac{\mathrm{n}}{2}\right], y=[1991, \ldots, 2002]$

$15 \mathrm{c}_{j, y}=$ daily max ozone concentration at day $j$ and year $y$

$\mathrm{n}=30$ days

Then, for each day $i$ through a year's cycle a linear regression was calculated based on the 12 annual values of the 30 days' running values $\left(\hat{C}_{i, y}\right)$ that date in the 20 following manner:

$\hat{C}_{i, y}=\mathrm{a}_{\mathrm{i}} \mathrm{Y}+\mathrm{b}_{\mathrm{i}}, \quad i=[1, \ldots, 365], \mathrm{Y}=[1991, \ldots, 2002]$

The coefficients $a_{i}$ and $b_{i}$ determined from linear regression of Eq. (5) where then used to calculate the trend-adjusted 30 days' running medians (and 10- and 90-percentiles) for 2003 by extrapolation. For each day these trend-adjusted values for 2003 were used if the linear regression (Eq. 5) for that day was statistically significant different from zero.

Ozone in Europe 2003

S. Solberg et al.

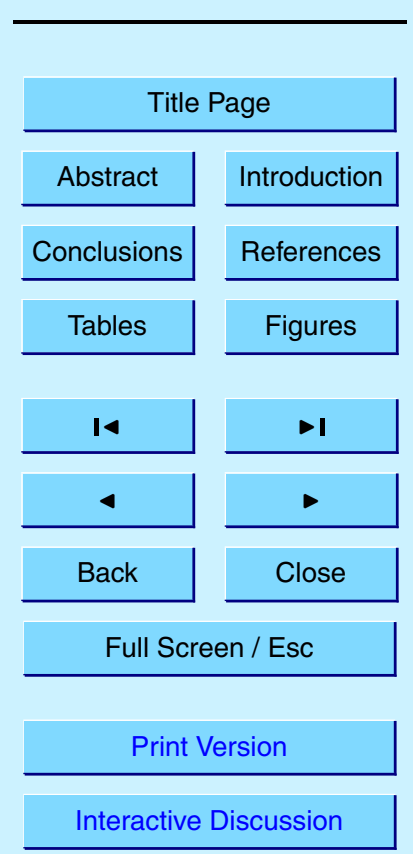

EGU 
Else the median values for all years were used. The reference concentration valid for day $i$ in $2003, C_{i}^{*}$, is thus given by:

ACPD

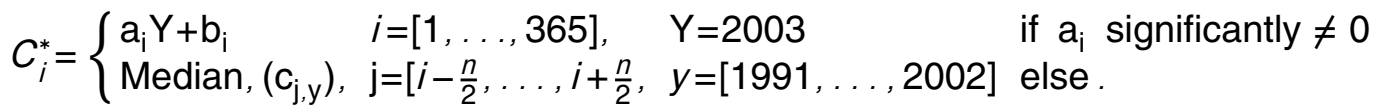

The ozone time series measured in 2003 relative to the reference climatology are 5 shown in Figs. 4, 5 and 6 for sites in the Nordic countries, Central Europe and UK+Ireland, respectively. The difference between the green line (the not trend-adjusted reference) and the blue line (trend-adjusted reference) indicates the change from the 1991-2002 reference to the 2003 data that could be ascribed to the long-term trends in ozone whereas the difference between the red line (2003) and the blue line indicates 10 the 2003 anomaly.

In July and August 2003 Scandinavia experienced positive monthly temperature anomalies of around $2^{\circ} \mathrm{C}$ but was located outside the main area of the heat waves. The 2003 ozone anomaly is most evident at the most southern site, SE11 (Vavihill) and, surprisingly, also at SE13 (Esrange) in northern Sweden in July (Fig. 4). The mea15 surements at NO15 (Tustervatn) indicate a marked long-term ozone increase through the whole year while few signs of the 2003 anomaly.

At the sites in central Europe (Fig. 5) the indications of a long-term change in ozone is fairly small although an increase is indicated in winter/spring at some sites (DE02, DE04, AT04, CH02). The 2003 data, however, show up as a very strong deviation 20 from the reference climatology. This is particularly true for August and June and most pronounced at DE08 (Schmücke), DE04 (Deuselbach), CH02 (Payerne) and AT04 (St. Koloman). During these periods the running median values for 2003 often exceeded the running 90 -percentiles of the reference climatology.

The data from the UK sites (Fig. 6) indicate a long-term reduction in the summer ozone values and, at some sites, an increase in winter/spring when comparing the trend-adjusted and not trend-adjusted data for the 1991-2002 period. A 2003 ozone anomaly is clearly seen at the southern sites (GB36, GB38 and GB13) and to a less

Ozone in Europe 2003

S. Solberg et al.

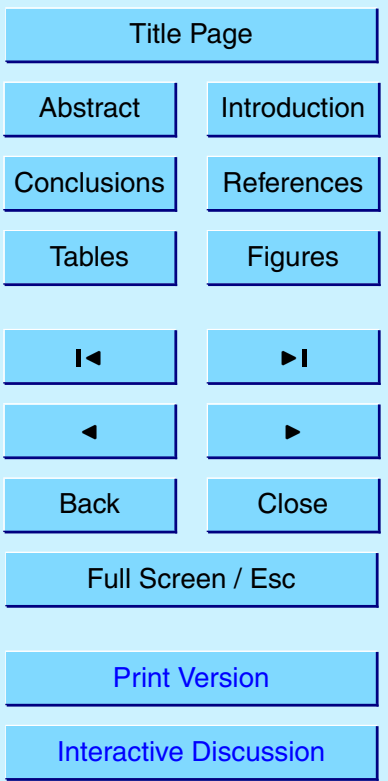

EGU 
extent at Mace Head (IE31), whereas at GB02, Eskedalmuir in Scotland, there is no clear sign of the 2003 period.

\section{Residence time in the European boundary layer}

Based on the FLEXTRA 3-dimensional air mass back-trajectories (Stohl et al., 1995; 5 Stohl and Seibert, 1998) we have estimated the residence times in the European planetary boundary layer (PBL) for air masses arriving at a number of monitoring sites in Europe as shown in Fig. 7. This was done by computing the number of hours the trajectories stayed within the European domain and below a vertical level which was set to $2.5 \mathrm{~km}$ above sea level. The European domain was defined to be the area between ${ }_{10} 10^{\circ} \mathrm{E}, 30^{\circ} \mathrm{W}, 35^{\circ} \mathrm{N}$ and $55^{\circ} \mathrm{N}$ (Fig. 7). The basis for the calculations were 7-days' backward trajectories arriving every six hours at 500 ma.s.l. for the period 1996-2003 for the given sites.

The results, presented in Fig. 8, show that for Rigi in Switzerland and Peyrusse Vieille in southern France the residence time in the European PBL was particularly 15 high in June and August. Also at Kosetice in the Czech Republic the residence time in the European PBL was high in June. At the other sites, further north (Mace Head and Waldhof) and east (Starina), the PBL residence times varied during summer, but without a clear perturbation. This is in line with the geographical distribution of the temperature anomalies which show the highest values in south- and central France, 20 Switzerland, southern Germany and northern Italy (Fink et al., 2004). It indicates that the situation was particularly favourable for long-term ozone formation in south- and central parts of Europe, whereas the regions to the north and east was more at the outskirts of the anticyclone and to a higher extent a receiver of photochemically processed air masses.
ACPD

5, 9003-9038, 2005

\section{Ozone in Europe 2003}

S. Solberg et al.

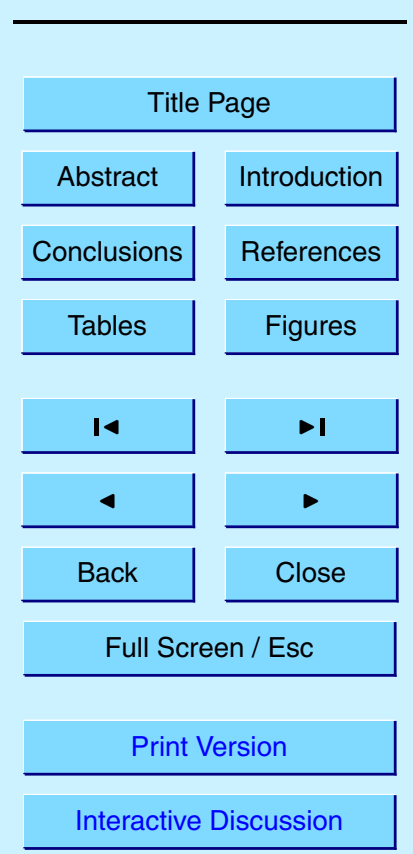

EGU 


\section{Carbon monoxide}

NOAA CMDL has measured $\mathrm{CO}$ at a number of global sites for several years (Novelli et al., 1998, 2003). Ambient and standard air samples are injected into the gas chromatograph. Carbon monoxide $(\mathrm{CO})$ and molecular hydrogen $\left(\mathrm{H}_{2}\right)$ are separated from other 5 sample constituents using dual columns. $\mathrm{CO}$ and $\mathrm{H}_{2}$ are reacted with hot $\mathrm{HgO}$ bed to produce mercury $(\mathrm{Hg})$. $\mathrm{Hg}$ is then determined photometrically. The non-linear detector requires a multipoint calibration using 6 standards in the atmospheric range. Reproducibility of the measurements, based on repeated analysis of air from a high-pressure cylinder, is $1 \mathrm{nmol} \mathrm{mol}^{-1}$ at $50 \mathrm{nmol} \mathrm{mol}^{-1}$ and $2 \mathrm{nmol} \mathrm{mol}^{-1}$ at $200 \mathrm{nmol} \mathrm{mol}^{-1}$. The

air samples are collected by flushing and then pressurizing glass flasks with a pump. During each sampling event, a pair of flasks is filled.

NOAA has sampled $\mathrm{CO}$ weekly in canisters at two European sites: Weathership $\mathrm{M}$ $\left(66^{\circ} \mathrm{N} 2^{\circ} \mathrm{E}\right)$ and $\mathrm{Ny}$-Ålesund $\left(78^{\circ} 54^{\prime} \mathrm{N}, 11^{\circ} 53^{\prime} \mathrm{E}\right)$ at Spitsbergen. The weekly data and the smoothed time series are shown in Fig. 9. The $\mathrm{CO}$ data show a marked seasonal cycle with minimum values in summer and maximum values in winter. Elevated summer concentrations are clearly seen in 1998 and 2003 at Weathership M, and, to a less extent, at Spitsbergen and were likely due to intense boreal forest fires. It has previously been shown that large forest fires in Canada polluted the lower troposphere over Europe in August 1998 (Forster et al., 2001) and that the 1998 summer CO concentrations were enhanced in the whole northern hemisphere due to massive forest fires in Siberia and Canada (Yurganov et al., 2004). Recent studies have indicated that during summer of 2003, biomass fires burned a large area of Siberia, the largest in at least 10 years (Jaffe et al., 2004; Honrath et al., 2004; Yurganov et al., 2005) and that the background concentration of both $\mathrm{CO}$ and $\mathrm{O}_{3}$ were enhanced at many sites in the northern hemisphere.

In 2003 the Siberian boreal forest fires started already in early spring and intensified towards July and August. Plumes of Siberian forest fires in May 2003 have been shown to have travelled effectively around the globe and have been identified over
ACPD

5, 9003-9038, 2005

Ozone in Europe 2003

S. Solberg et al.

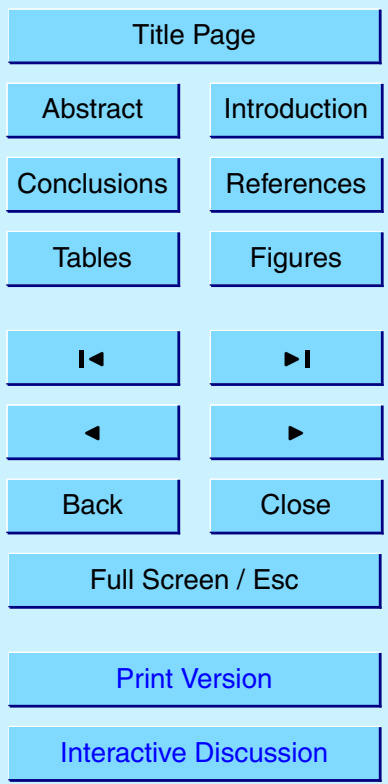

EGU 
both the North American and European continent (Damoah et al., 2004). According to Yurganov et al. (2005) maximum anomalies in tropospheric column $\mathrm{CO}$ abundances were observed over most of the northern hemisphere during August 2003 and September 2002. In May and early June 2003 distinct layers with enhanced aerosol concen5 trations were observed above the boundary layer of Leipzig, Germany, that have been linked to the severe forest fires in Siberia (Mattis et al., 2003).

In western North America the enhanced CO concentrations due to the Siberian fires in 2003 were accompanied by elevated $\mathrm{O}_{3}$ concentrations (Jaffe et al., 2004). At Barrow (Alaska) the summer of 2003 had the highest mean CO concentrations ever seen, 10 and the third highest $\mathrm{O}_{3}$ value out of 31 years of observations. The sites in Northwest America are closer to the source regions in Siberia and therefore more exposed to the burning events than European sites. It is, however, likely that these large-scale burning episodes increased the background level of tropospheric ozone at northern latitudes in general.

15 Recently it has been shown that also at Mace Head there is a strong correlation between surface ozone (and other greenhouse gases) and large-scale biomass burning events (Simmonds et al., 2005). Peak ozone episodes in Europe in 2003 may thus have been further enhanced as they came on top of an elevated background ozone level caused by the massive Siberian forest fires. This illustrates a positive feedback mechanism between global warming and tropospheric ozone. Ozone itself is an important greenhouse gas, and with a warmer and dryer climate the risk of fires increases thereby leading to further ozone formation.

\section{Isoprene}

Isoprene has been measured at Donon $\left(48^{\circ} 30^{\prime} \mathrm{N}, 7^{\circ} 08^{\prime} \mathrm{E}\right)$ in southeast France since 251997 as part of the EMEP VOC monitoring programme (Borbon, 2004; Solberg, 2004). The samples are collected in electro polished stainless steel canisters twice a week and subsequently analysed by GC/FID for about twenty $\mathrm{C}_{2}-\mathrm{C}_{7}$ individual light hydrocarbons
ACPD

5, 9003-9038, 2005

\section{Ozone in Europe 2003}

S. Solberg et al.

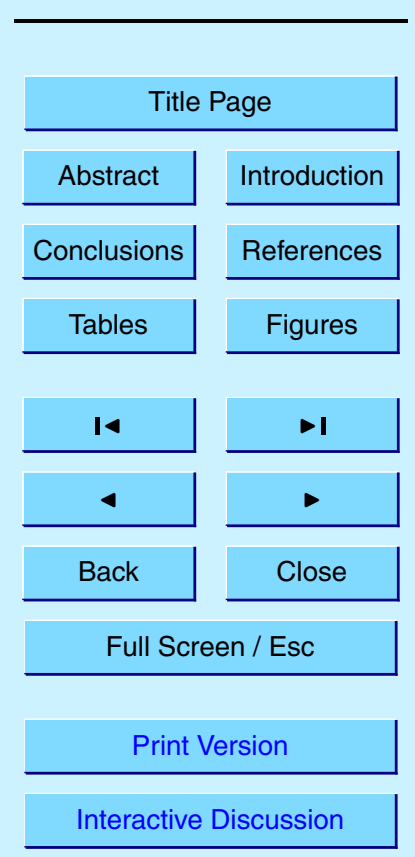

EGU 
by the laboratory of Ecole des Mines des Douai (EMD) in France. Figure 10 shows the measured isoprene data from 1997 to 2003 at Donon. Whereas the running average concentration peaked at approx. $1 \mathrm{ppb}$ in the summers of 1998-2002, the concentration level in summer 2003 was about twice this value. Also in summer 1997 the mean 5 isoprene level was elevated but not as much as in 2003. Biogenic isoprene emissions are strongly controlled by solar radiation and surface temperatures (Guenther et al., 1993; Simpson et al., 1995). The elevated isoprene concentrations observed at Donon thus indicates increased biogenic emissions coinciding with the elevated temperature and solar radiation during summer 2003. In a previous study of this station, Borbon et 10 al. (2004) concluded that in summer, in-situ biogenic emissions dominate at least $80 \%$ of isoprene, whereas, in winter, more than $90 \%$ of residual rural isoprene comes from urban air mass mixing. Additionally, the surface isoprene concentrations could also be enhanced compared to normal summer conditions due to reduced vertical mixing associated with stable, anticyclonic conditions.

15 The possible effect of the elevated isoprene levels for enhanced ozone formation is an open question, and depends on the $\mathrm{NO}_{\mathrm{x}}$-concentration level and whether the isoprene is emitted into an area where ozone formation is $\mathrm{NO}_{\mathrm{x}}-$ or VOC-limited. Previous calculations with the Lagrangian EMEP oxidant model (Simpson, 1995) indicated that mean ozone levels in Europe were fairly insensitive to isoprene as the major part of the isoprene emission was in $\mathrm{NO}_{\mathrm{x}}$-limited regions, whereas in VOC-limited areas anthropogenic VOCs dominated over biogenic VOCs. For peak ozone values, however, a larger effect of isoprene emissions were calculated.

Thus we conclude, that both the meteorological situation as well as isoprene measurements indicate that Europe experienced significantly elevated biogenic emissions during the extreme summer 2003 , with a potential for increased ozone peak values, while the magnitude of this contribution has to be investigated by model sensitivity calculations.
ACPD

5, 9003-9038, 2005

\section{Ozone in Europe 2003}

S. Solberg et al.

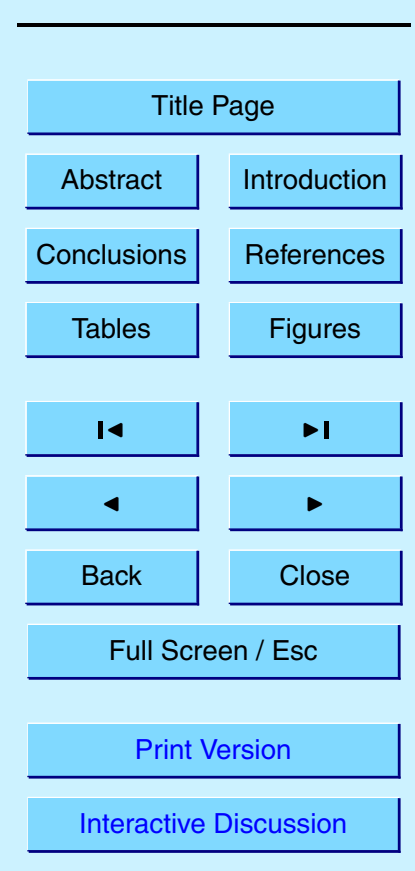

EGU 


\section{Total ozone}

Orsolini and Nikulin (2005) have shown evidence of an episode of a low total ozone column (LOE) over northern Europe during the heat wave in mid-August 2003. The LOE peaked over Scandinavia and the North Sea around 10 August (Fig. 11), at the 5 peak time of the central Europe heat wave. During the August heat wave low-ozone stratospheric air extended southwards from the Arctic toward northern Europe, as the large-scale circulation in the lower and mid-stratosphere was perturbed by large-scale waves. Combined to the column ozone lowering by the anticyclonic conditions, this southward displacement of stratospheric Arctic air led to a column abundance as low Nikulin, 2005).

The low ozone column over North Europe could have a potential effect for the photochemical ozone formation in the lower troposphere during the heat wave. A reduced total ozone column will particularly alter the photolysis rate of $\mathrm{O}_{3} \rightarrow \mathrm{O}^{\prime} \mathrm{D}$ which in turn 15 may increase the $\mathrm{OH}$ concentration and thereby speed up the general oxidation rate of the troposphere. Model calculations by Jonson et al. (2000) indicated that the effect of a modest 25DU increase in the ozone column had small effects for the modelled monthly mean surface ozone concentration in the Mediterranean area. However, the effect of the observed LOE for the hourly peak surface ozone values remains to be investigated.

\section{Forest fires on the Iberian Peninsula}

The extended drought, sunshine and high surface temperatures caused forest fires in many parts of Europe, particularly in the south, and most pronounced in Portugal and Spain. The Iberian Peninsula experienced periods of extensive forest fires during July to September. In the first half of August, coinciding with the peak heat wave in central and northern Europe, massive fires were observed in Portugal, as seen from the Terra
ACPD

5, 9003-9038, 2005

Ozone in Europe 2003

S. Solberg et al.

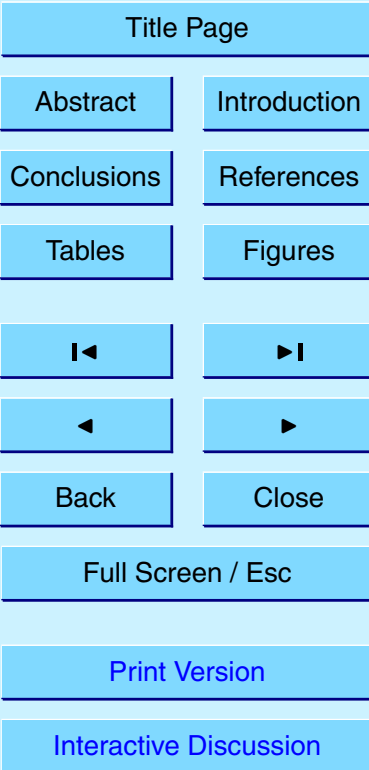

EGU 
satellite on 4 August (Fig. 12).

To look for possible links between the Portuguese forest fires and the ozone episode further north we performed backward simulations with the Lagrangian particle dispersion model FLEXPART (Stohl et al., 1998). Details on the backward simulations can 5 be found in Seibert and Frank (2004). FLEXPART parameterizes turbulence (Stohl and Thomson, 1999), is equipped with a convective parameterization scheme (Emanuel and Zivkovic-Rothman, 1999), and was validated in a number of studies on air pollution transport (e.g. Wotawa and Trainer, 2000; Forster et al., 2001; Spichtinger et al., 2001; Stohl et al., 2003). The simulations for this study are based on operational data 10 (horizontal resolution of $1^{\circ} \times 1^{\circ}, 61$ vertical levels, temporal resolution of $3 \mathrm{~h}$ ) from the European Centre for Medium-Range Weather Forecasts (ECMWF, 1995). At the (receptor) site Eupen, Belgium, the site where the highest ozone value within the EMEP network was measured (Table 1), 20000 particles with unit mixing ratio were released every 6-h interval between 1 and 12 August and followed 20 days backward in time.

15 A response function to emission input which is related to the particles' residence time and can be used to determine the source regions and pathways of air masses to the receptor, was then calculated on a uniform grid.

Figure 13 shows the sum of the total columns of the sensitivity function over the last 3 to 20 days before arrival on 7 August between 00:00 and 06:00 UTC at Eupen.

20 The air masses originate mainly from the Gulf of Biscaya and the western parts of the Iberian Peninsula, close to where the forest fires burned during the first half of August. High values of the response function can also be found over Northern Germany and parts of the Netherlands indicating that the air masses at Eupen is a mixture of air from relatively close sources and air transported over longer distances. Similar patterns in 25 the source regions and the pathways of air masses to Eupen were found for the 8 to 12 August (not shown), whereas before the 6 August transport from the Atlantic and North America dominated. A closer look at the FLEXPART results indicate a transport time from the Iberian Peninsula of the order of 4 days. These results clearly indicate that the forest fires in Portugal/Spain during August could indeed have contributed to

ACPD

5, 9003-9038, 2005

Ozone in Europe 2003

S. Solberg et al.

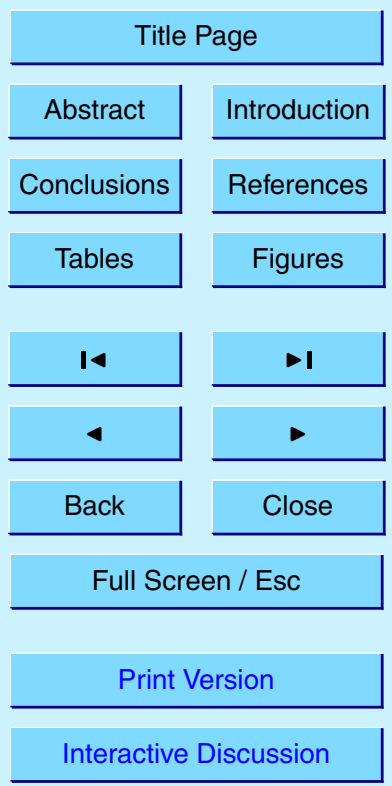

EGU 


\section{Conclusions}

5, 9003-9038, 2005

The extreme heat waves and drought that Europe experienced in 2003 were accompanied by record-high surface ozone values in central Europe. The highest peak values were for most of the sites observed in August 2003 when the most intense heat wave occurred and in June. High ozone concentrations were also observed in southern UK but mostly lower than the peak values during the previous decade. The ozone extreme values occurred in spite of a substantial reduction in the average emission of anthropogenic ozone precursors ( $\mathrm{NO}_{x}$ and $\mathrm{VOC}$ ) that has taken place in Europe during the 10 1990s and is clearly linked to the meteorological conditions. As the heat wave intensified the emissions of natural biogenic VOC increased significantly, the residence time of air parcels in the boundary layer went up, the ozone column was lower than normal, the cloud cover was low and most importantly, the removal mechanism due to dry deposition was reduced due to stomata closure of plants under drought stress. In 15 addition, massive forest fires in Portugal and Spain, initiated by the extreme drought and heat, likely contributed to the ozone peak values in north Europe in August 2003. Furthermore, the hemispherical background levels of ozone and $\mathrm{CO}$ were presumably elevated due to boreal forest fires in Siberia. Thus, the 2003 summer is a "field example" of the close link between meteorological conditions and a secondary pollutant

20 like ozone and is also relevant for particulate matter. Climate model scenarios have indicated that extreme weather events like this may become more frequent in the future. Thus, the effect of future climate change may gradually outweigh the benefit of the emission abatement in Europe for secondary photochemical pollutants.

Acknowledgements. We are very thankful for the $\mathrm{CO}$ data provided by $\mathrm{P}$. Novelli at 25 NOAA/CMDL and for the meteorological data for FLEXTRA and FLEXPART provided by ECMWF. The TERRA satellite picture was retrieved from Internet by courtesy of the MODIS

\section{Ozone in Europe 2003}

S. Solberg et al.

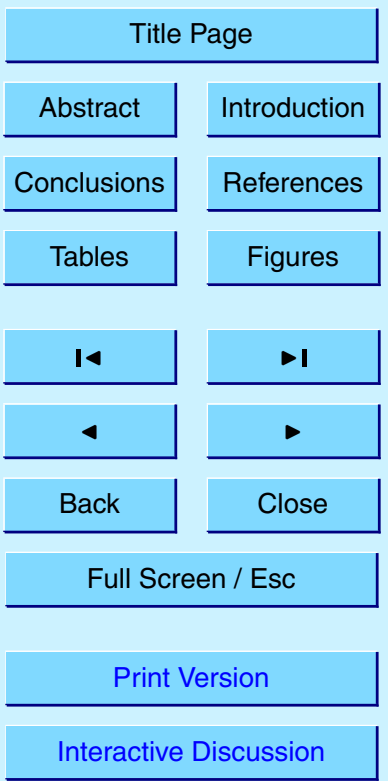

EGU 
Rapid Response Project at NASA/GSFC and the TOMS picture by courtesy of the Ozone Processing Team at NASA/GSFC. This study was sponsored by EMEP (European Monitoring and Evaluation Programme) and the European Commission through the project NEPAP (Network for the support of European Policies on Air Pollution), EVK2-CT-2002-80019.

\section{References}

Aas, W., Hjellbrekke, A. G., Schaug, J., and Solberg, S.: Data quality 1999, quality assurance, and field comparisons, EMEP-CCC Report 6/2001, Norwegian Institute for Air Research, P.O. Box 100, NO-2027 Kjeller, Norway, URL: http://www.nilu.no/projects/ccc/reports.html, 2001.

Beniston, M.: The 2003 heat wave in Europe: A shape of things to come? An analysis based on Swiss climatological data and model simulations, Geophys. Res. Lett., 31, L02202, doi:10.1029/2003GL018857, 2004.

Black, E., Blackburn, M., Harrison, G., Hoskins, B. J., and Methven, J.: Factors contributing to the summer 2003 european heatwave, Weather, 59, 217-223, 2004.

15 Borbon A., Coddeville, P., Locoge N., and Galloo, J. C.: Characterising sources and sinks of rural VOC in eastern France, Chemosphere, 57, 931-942, 2004.

Damoah, R., Spichtinger, N., Forster, C., James, P., Mattis, I., Wandinger, U., Beirle, S., Wagner, T., and Stohl, A.: Around the world in 17 days - hemispheric-scale transport of forest fire smoke from Russia in May 2003, Atmos. Chem. Phys., 4, 1311-1321, 2004, SRef-ID: 1680-7324/acp/2004-4-1311.

ECMWF: User Guide to ECMWF Products 2.1, Meteorological Bulletin M3.2, ECMWF, Reading, UK, 1995.

Emanuel, K. A. and Zivkovic-Rothman, M.: Development and evaluation of a convection scheme for use in climate models, J. Atmos. Sci., 56, 1766-1782, 1999.

EMEP: EMEP manual for sampling and chemical analysis, EMEP-CCC Report 1/95, Norwegian Institute for Air Research, P.O. Box 100, NO-2027 Kjeller, Norway, URL: http: //www.nilu.no/projects/ccc/submission.html, 1996.

Fiala, J., Cernikovsky, L., de Leeuw, F., and Kurfuerst, P.: Air pollution by ozone in Europe in summer 2003. Overview of exceedances of EC ozone threshold values during the summer
ACPD

5, 9003-9038, 2005

Ozone in Europe 2003

S. Solberg et al.

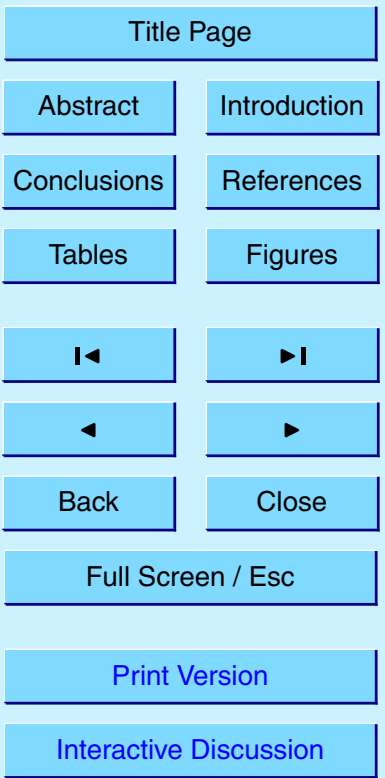

EGU 
season April-August 2003 and comparisons with previous years. Copenhagen, European Environment Agency (EEA Topic Report 3/2003), 2003.

Fink, A. H., Brucher, T., Kruger, A., Leckebusch, G. C., Pinto, J. G., and Ulbrich, U.: The 2003 European summer heatwaves and drought - synoptic diagnosis and impacts, Weather 59, 5 209-216, 2004.

Fischer, P. H., Brunekreef, B., and Lebret, E.: Air pollution related deaths during the 2003 heat wave in the Netherlands, Atmos. Environ., 38, 1083-1085, 2003.

Forster, C., Wandinger, U., Wotawa, G., James, P., Mattis, I., Althausen, D., Simmonds, P., O'Doherty, S., Jennings, S. G., Kleefeld, C., Schneider, J., Trickl, T., Kreipl, S., Jäger, H., and Stohl, A.: Transport of boreal forest fire emissions from Canada to Europe, J. Geophys. Res., 106, 22 887-22 906, doi:10.1029/2001JD900115, 2001.

Fricke, W.: Der Sommer 2003 in der 222-jaehrigen Messreihe am Hohenpeissenberg. GAWBrief, 18, Deutscher Wetterdienst, URL: http://www.meteo.uni-koeln.de/content/forschung/ klimadiagnose/summerheat2003/gaw_brief_018.pdf, 2003.

Grazzini, F., Ferranti, L., Lalaurette, F., and Vitart, F.: The exceptional warm anomalies of summer 2003, ECMWF Newsletter, 99, 2-8, 2003.

Guenther, A. B., Zimmerman, P. R., Harley, P. C., Monson, R. K., and Fall, R.: Isoprene and monoterpene emission rate variability: model evaluations and sensitivity analyses, J. Geophys. Res., 98, 12609-12617, 1993.

Hjellbrekke, A. G. and Solberg, S.: Ozone measurements 2002, EMEP-CCC Report 2/2004, Norwegian Institute for Air Research, P.O. Box 100, NO-2027 Kjeller, Norway, URL: http: //www.nilu.no/projects/ccc/reports.html, 2004.

Honrath, R. E., Owen, R. C., Val Martin, M., Reid, J. S., Lapina, K., Fialho, P., Dziobak, M. P., Kleissl, J., and Westphal, D. L.: Regional and hemispheric impacts of anthropogenic and biomass burning emissions on summertime $\mathrm{CO}$ and $\mathrm{O}_{3}$ in the North Atlantic lower free troposphere, J. Geophys. Res., 109, D24310, doi:10.1029/2004JD005147, 2004.

Jaffe, D., Bertschi, I., Jaegle, L., Novelli, P., Reid, J. S., Tanimotot, H., Vingarzan, R., and Westphal, D. L.: Long-range transport of Siberian biomass burning emissions and impact on surface ozone in western North America, Geophys. Res. Lett., 31, L16106, doi:10.1029/2004GL020093, 2004.

Jonson J. E., Kylling, A., Berntsen, T. K., Isaksen, I. S. A., Zerefos, C. S., and Kourtidis, K.: Chemical effects of UV fluctuations inferred from total ozone and tropospheric aerosol variations, J. Geophys. Res., 105, 14561-14574, 2000.
ACPD

5, 9003-9038, 2005

Ozone in Europe 2003

S. Solberg et al.

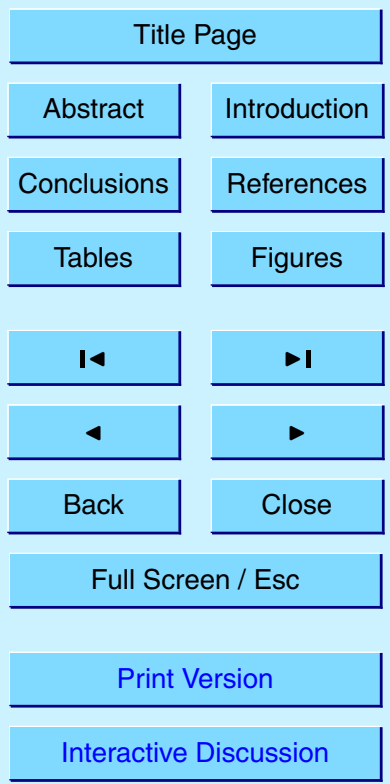

EGU 
Laurila, T., Tuovinen, J. P., Tarvainen, V., and Simpson, D.: Trends and scenarios of groundlevel ozone concentrations in Finland, Boreal Environ. Res., 9, 167-184, 2004.

Luterbacher, J., Dietrich, D., Xoplaki, E., Grosjean, M., and Wanner, H.: European seasonal and annual temperature variability, trends, and extremes since 1500, Science, 303, 14991503, 2004.

Mattis, I., Ansmann, A., Wandinger, U., and Muller, D.: Unexpectedly high aerosol load in the free troposphere over central Europe in spring/summer 2003, Geophys. Res. Lett., 30, 2178, doi:10.1029/2003GL018442, 2003.

NEGTAP (National Expert Group on Transboundary Air Pollution): Transboundary air pollution: acidification, eutrophication and ground-level ozone in the UK, Edinburgh, National Expert Group on Transboundary Air Pollution, URL: http://www.nbu.ac.uk/negtap/, 2001

Novelli, P. C., Masarie, K. A., and Lang, P. M.: Distributions and recent changes in carbon monoxide in the lower troposphere, J. Geophys. Res., 103, 19 015-19 033, 1998.

Novelli, P. C., Masarie, K. A., Lang, P. M., Hall, B. D., Myers, R. C., and Elkins, J. W.: Re15 analysis of tropospheric CO trends: Effects of the 1997-1998 wild fires, J. Geophys. Res., 108, 4464, doi:10.1029/2002JD0030312003, 2003.

Ordonez, C., Mathis, H., Furger, M., Henne, S., Huglin, C., Staehelin, J., and Prevot, A. S. H.: Changes of daily surface ozone maxima in Switzerland in all seasons from 1992 to 2002 and discussion of summer 2003, Atmos. Chem. Phys., 5, 1187-1203, 2005,

20 SRef-ID: 1680-7324/acp/2005-5-1187.

Orsolini, Y. J. and Nikulin, G.: A low-ozone episode during the European heat wave of August 2003, Q. J. Roy. Met. Soc., 131, in press, 2005.

Schär, C., Vidale, P. L., Lüthl, D., Frei, C., Häberli, C., Liniger, M. A., and Appenzeller, C.: The role of increasing temperature variability in European summer heatwaves, Nature, 427,

$25 \quad 332-336,2004$.

Seibert, P. and Frank, A.: Source-receptor matrix calculation with a Lagrangian particle dispersion model in backward mode, Atmos. Chem. Phys., 4, 51-63, 2004,

SRef-ID: 1680-7324/acp/2004-4-51.

Simmonds, P. G., Derwent, R. G., Manning, A. L., and Spain, G.: Significant growth in surface ozone at Mace Head, Ireland, 1987-2003, Atmos. Environ., 38, 4769-4778, 2004.

Simmonds, P. G., Manning, A. J., Derwent, R. G., Ciais, P., Ramonet, M., Kazan, V., and Ryall, D.: A burning question. Can recent growth rate anomalies in the greenhouse gases be attributed to large-scale biomass burning events?, Atmos. Environ., 39, 2513-2517, 2005.

ACPD

5, 9003-9038, 2005

\section{Ozone in Europe 2003}

S. Solberg et al.

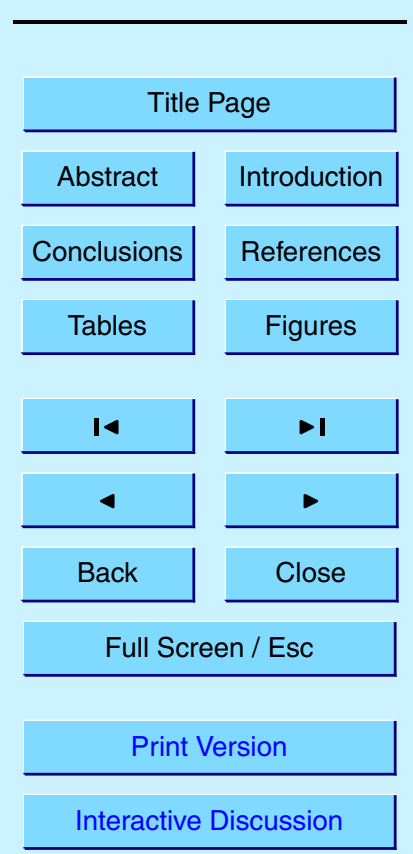

EGU 
Simpson, D., Guenther, A., Hewitt, C. N., and Steinbrecher, R.: Biogenic emissions in Europe 1. Estimates and uncertainties, J. Geophys. Res., 100, 22 875-22 890, 1995.

Simpson, D.: Biogenic emissions in Europe 2. Implications for ozone control strategies, J. Geophys. Res., 100, 22 891-22 906, 1995.

5 Solberg, S.: VOC measurements 2002, EMEP CCC Report 8/2004, Norwegian Institute for Air Research, P.O. Box 100, NO-2027 Kjeller, Norway, URL: http://www.nilu.no/projects/ccc/ reports.html, 2004.

Solberg, S., Derwent, R. G., Hov, Ø., Langner, J., and Lindskog, A.: European abatement of surface ozone in a global perspective, Ambio, 34, 47-53, 2005.

10 Spichtinger, N., Wenig, M., James, P., Wagner, T., Platt, U., and Stohl, A.: Satellite detection of a continental-scale plume of nitrogen oxides from boreal forest fires, Geophys. Res. Lett., 28, 4579-4582, 2001.

Stedman, J. R.: The predicted number of air pollution related deaths in the UK during the August 2003 heatwave, Atmos. Environ., 38, 1087-1090, 2003.

Stohl, A., Wotawa, G., Seibert, P., and Kromp-Kolb, H.: Interpolation errors in wind fields as a function of spatial and temporal resolution and their impact on different types of kinematic trajectories, J. Appl. Meteor., 34, 2149-2165, 1995.

Stohl, A. and Seibert, P.: Accuracy of trajectories as determined from the conservation of meteorological tracers, Q. J. Roy. Met. Soc., 124, 1465-1484, 1998.

20 Stohl, A., Hittenberger, M., and Wotawa, G.: Validation of the Lagrangian particle dispersion model FLEXPART against large scale tracer experiment data, Atmos. Environ., 32, 42454264, 1998.

Stohl, A. and Thomson, D. J.: A density correction for Lagrangian particle dispersion models, Bound.-Layer Met., 90, 155-167, 1999.

Stohl, A., Forster, C., Eckhardt, S., Spichtinger, N., Huntrieser, H., Heland, J., Schlager, H., Wilhelm, S., Arnold, F., and Cooper, O.: A backward modeling study of intercontinental pollution transport using aircraft measurements, J. Geophys. Res., 108, 4370, doi:10.1029/2002JD002862, 2003.

Stott, P. A., Stone, D. A., and Allen, M. R.: Human contribution to the European heatwave of 2003, Nature, 432, 610-613, 2004.

Trigo R. M., García-Herrera, R., Díaz, J., Trigo, I. F., and Valente, M. A.: How exceptional was the early August 2003 heatwave in France?, Geophys. Res. Lett., 32, L10701, doi:10.1029/2005GL022410, 2005.

ACPD

5, 9003-9038, 2005

Ozone in Europe 2003

S. Solberg et al.

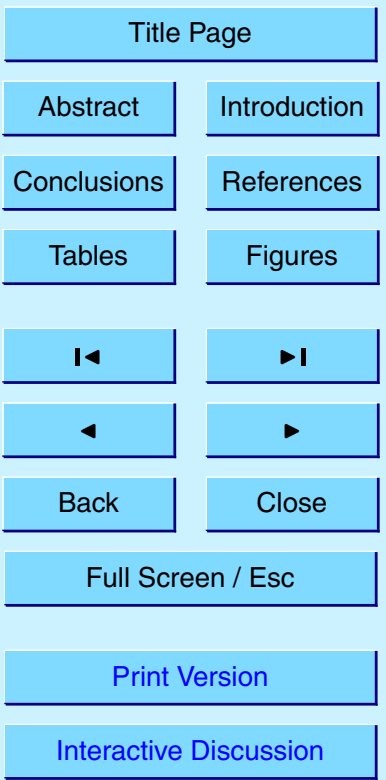

EGU 
Umweltbundesamt: Kurzbericht, Ozonsituation 2003 in der Bundesrepublik Deutschland, ACPD Umweltbundesamt, Berlin, URL: http://www.umweltbundesamt.org/fpdf-I/2500.pdf, November 2003.

Vautard, R., Honore, C., Beekmann, M., and Rouil, L.: Simulation of ozone during the August 52003 heat wave and emission control scenarios, Atmos. Environ., 39, 2957-2967, 2005.

Vestreng, V., Adams, M., and Goodwin, J.: Inventory Review 2004 Emission Data reported to CLRTAP and under the NEC Directive, EMEP/EEA Joint Review Report, EMEP MSC-W Technical Report 1/2004, Norwegian Meteorological Institute, P.O. Box 43 Blindern, NO-0313 Oslo, Norway, URL: http://www.emep.int/mscw/mscw_publications.html, 2004.

Wotawa, G. and Trainer, M.: The influence of Canadian forest fires on pollutant concentrations in the United States, Science, 288, 324-328, 2000.

Yurganov, L. N., Blumenstock, T., Grechko, E. I., Hase, F., Hyer, E. J., Kasischke, E. S., Koike, M., Kondo, Y., Kramer, I., Leung, F. Y., Mahieu, E., Mellqvist, J., Notholt, J., Novelli, P. C., Rinsland, C. P., Scheel, H. E., Schulz, A., Strandberg, A., Sussmann, R., Tanimoto, H., Velazco, V., Zander, R., and Zhao, Y.: A quantitative assessment of the 1998 carbon monoxide emission anomaly in the Northern Hemisphere based on total column and surface concentration measurements, J. Geophys. Res., 109, D15305, doi:10.1029/2004JD004559, 2004.

Yurganov, L. N., Duchatelet, P., Dzhola, A. V., Edwards, D. P., Hase, F., Kramer, I., Mahieu, E., Mellqvist, J., Notholt, J., Novelli, P. C., Rockmann, A., Scheel, H. E., Schneider, M., Schulz, A., Strandberg, A., Sussmann, R., Tanimoto, H., Velazco, V., Drummond, J. R., and Gille, J. C.: Increased Northern Hemispheric carbon monoxide burden in the troposphere in 2002 and 2003 detected from the ground and from space, Atmos. Chem. Phys., 5, 563-573, 2005, SRef-ID: 1680-7324/acp/2005-5-563.

\section{Ozone in Europe 2003}

S. Solberg et al.

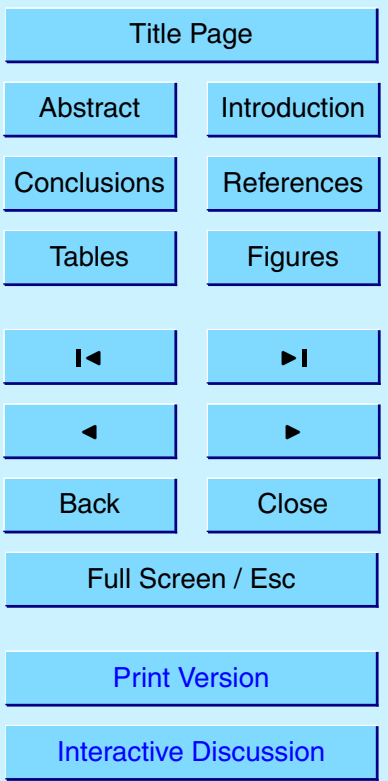

EGU 


\section{ACPD}

5, 9003-9038, 2005

Ozone in Europe 2003

Table 1. Location, magnitude and date of the 10 highest hourly ozone concentrations observed by the EMEP network in 2003.

\begin{tabular}{llcccc}
\hline Station name & Country & Longitude & Latitude & $\begin{array}{c}\text { Max value } \\
\left(\mu \mathrm{g} \mathrm{m}^{-3}\right)\end{array}$ & Date observed \\
\hline Eupen & Belgium & $6^{\circ} 00^{\prime} \mathrm{E}$ & $50^{\circ} 38^{\prime} \mathrm{N}$ & 296 & 8 Aug. 2003 \\
Montelibretti & Italy & $12^{\circ} 38^{\prime} \mathrm{E}$ & $42^{\circ} 06^{\prime} \mathrm{N}$ & 287 & 13 June 2003 \\
Donon & France & $7^{\circ} 08^{\prime} \mathrm{E}$ & $48^{\circ} 30^{\prime} \mathrm{N}$ & 254 & 11 Aug. 2003 \\
Harwell & UK & $1^{\circ} 19^{\prime} \mathrm{W}$ & $51^{\circ} 34^{\prime} \mathrm{N}$ & 246 & 15 July 2003 \\
Vreedepeel & The Netherlands & $5^{\circ} 51^{\prime} \mathrm{E}$ & $51^{\circ} 32^{\prime} \mathrm{N}$ & 244 & 7 Aug. 2003 \\
Schmücke & Germany & $10^{\circ} 46^{\prime} \mathrm{E}$ & $50^{\circ} 39^{\prime} \mathrm{N}$ & 243 & 12 Aug. 2003 \\
Vezin & Belgium & $4^{\circ} 59^{\prime} \mathrm{E}$ & $50^{\circ} 30^{\prime} \mathrm{N}$ & 239 & 8 Aug. 2003 \\
Revin & France & $4^{\circ} 38^{\prime} \mathrm{E}$ & $49^{\circ} 54^{\prime} \mathrm{N}$ & 239 & 8 Aug. 2003 \\
Bassum & Germany & $8^{\circ} 43^{\prime} \mathrm{E}$ & $52^{\circ} 51^{\prime} \mathrm{N}$ & 238 & 12 Aug. 2003 \\
Lullington Heath & UK & $0^{\circ} 11^{\prime} \mathrm{E}$ & $50^{\circ} 48^{\prime} \mathrm{N}$ & 236 & 11 Aug. 2003 \\
\hline
\end{tabular}

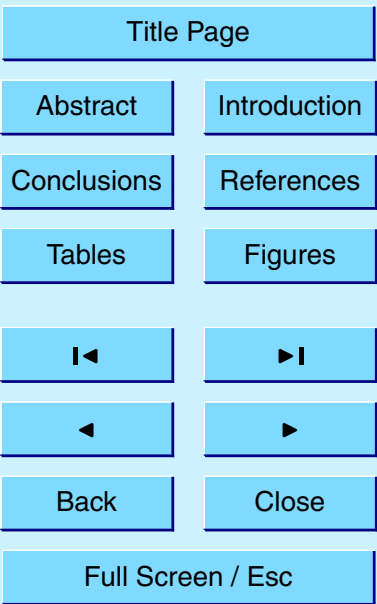

Print Version

Interactive Discussion

EGU 


\section{ACPD}

5, 9003-9038, 2005

Ozone in Europe 2003
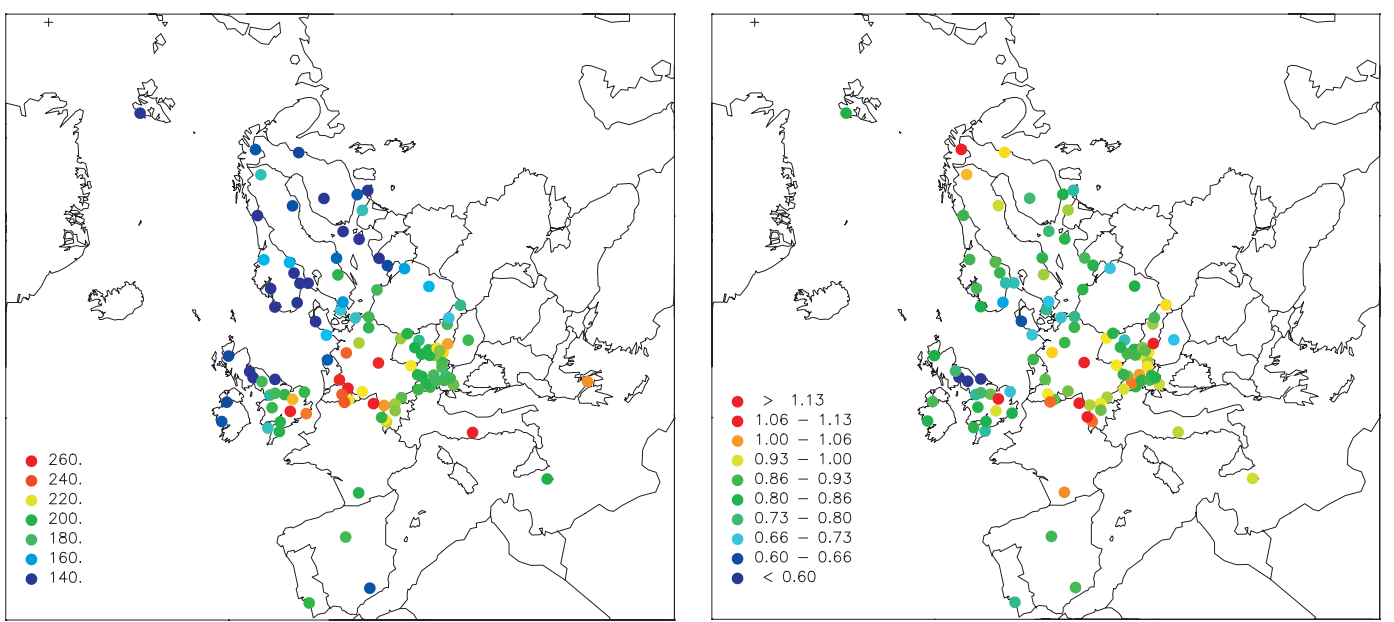

S. Solberg et al.

Fig. 1. Maximum hourly ozone concentrations observed in 2003 in $\mu \mathrm{g} \mathrm{m}^{-3}$ (left) and the same values relative to the maximum hourly ozone values observed during the period 1991-2002.

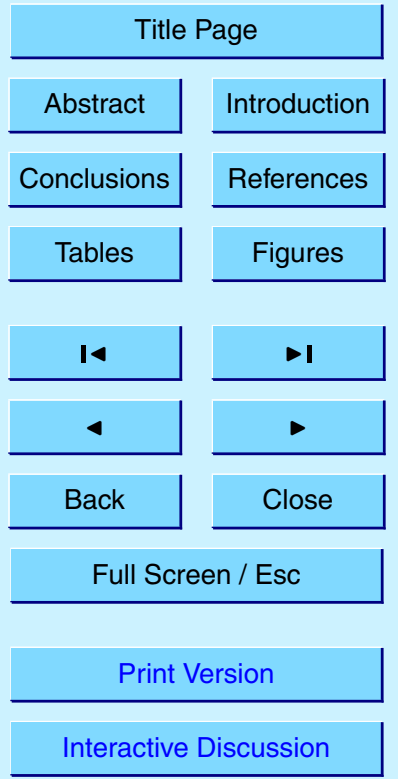

EGU 

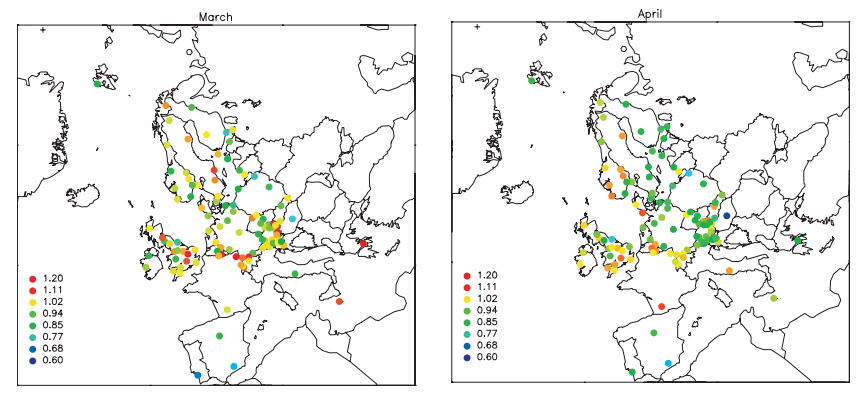

\section{ACPD}

5, 9003-9038, 2005
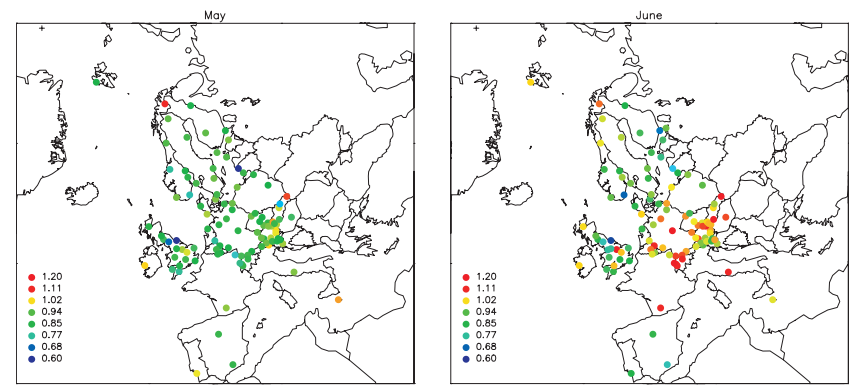

\section{Ozone in Europe} 2003

\section{S. Solberg et al.}
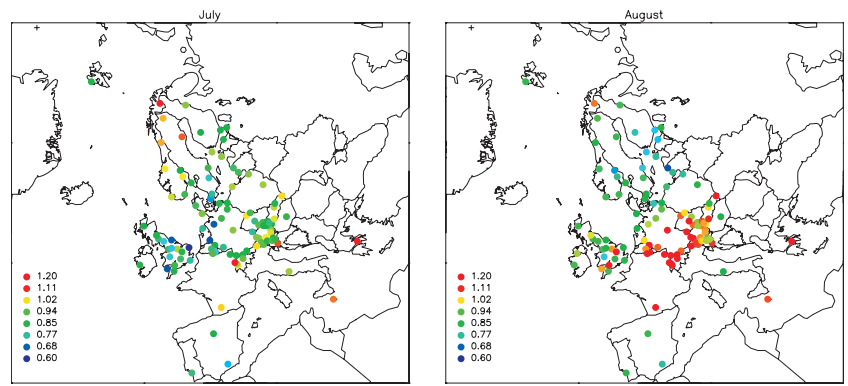

Title Page

\begin{tabular}{c|c} 
Abstract & Introduction \\
\cline { 1 - 1 } Conclusions & References \\
\cline { 1 - 1 } Tables & Figures
\end{tabular}

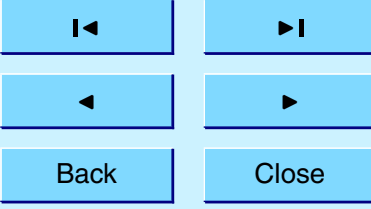

Full Screen / Esc

Print Version

Interactive Discussion

EGU

Fig. 2. Monthly means of daily maximum ozone concentration observed in 2003 relative to the maximum of the monthly means of daily maximum ozone during the years 1991-2002. 


\section{ACPD}

5, 9003-9038, 2005

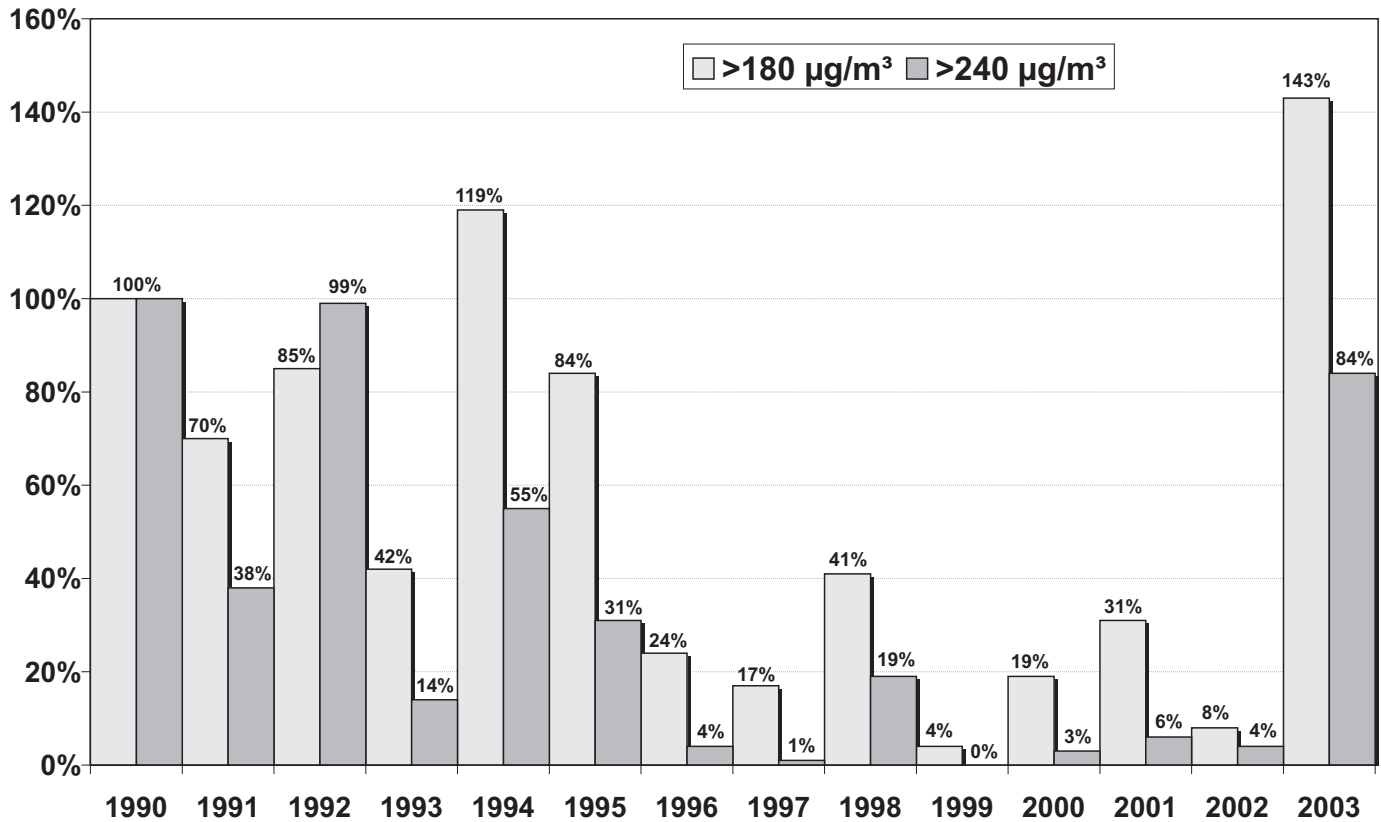

\section{Ozone in Europe 2003}

\section{S. Solberg et al.}

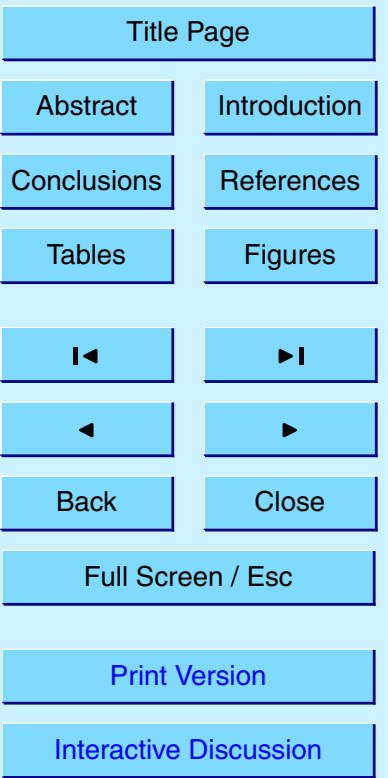

Fig. 3. The hours of hourly exceedances of the threshold level of $180 \mu \mathrm{g} \mathrm{m}^{-3}$ for all German ozone monitoring sites (EMEP and national) relative to the year 1990 and relative to the number of sites (Umweltbundesamt, 2003). 


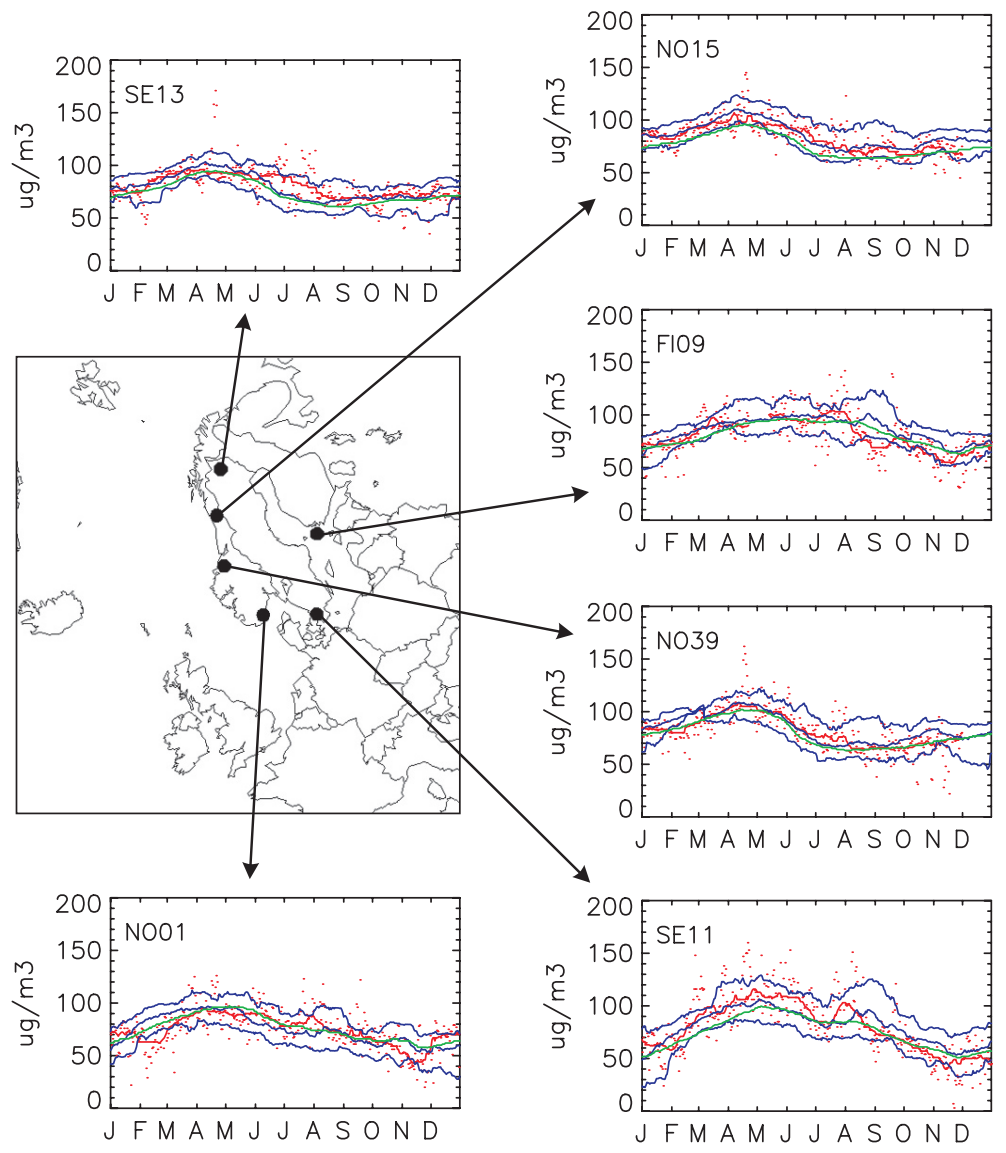

ACPD

5, 9003-9038, 2005

Ozone in Europe 2003

S. Solberg et al.

\section{Title Page}

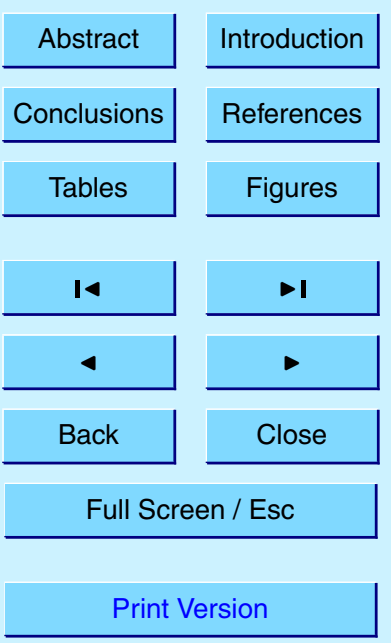

Interactive Discussion

Fig. 4. 30 days' running median ozone values (1991-2002) trend-adjusted (thick blue) and not trend-adjusted (green) as explained in the text, and the corresponding 30 days' running 10-percentile and 90 percentile (thin blue); 30 days' running median ozone values for 2003 (red

\section{Interactive Discussion}

EGU concentrations in $\mu \mathrm{g} \mathrm{m}^{-3}$. 


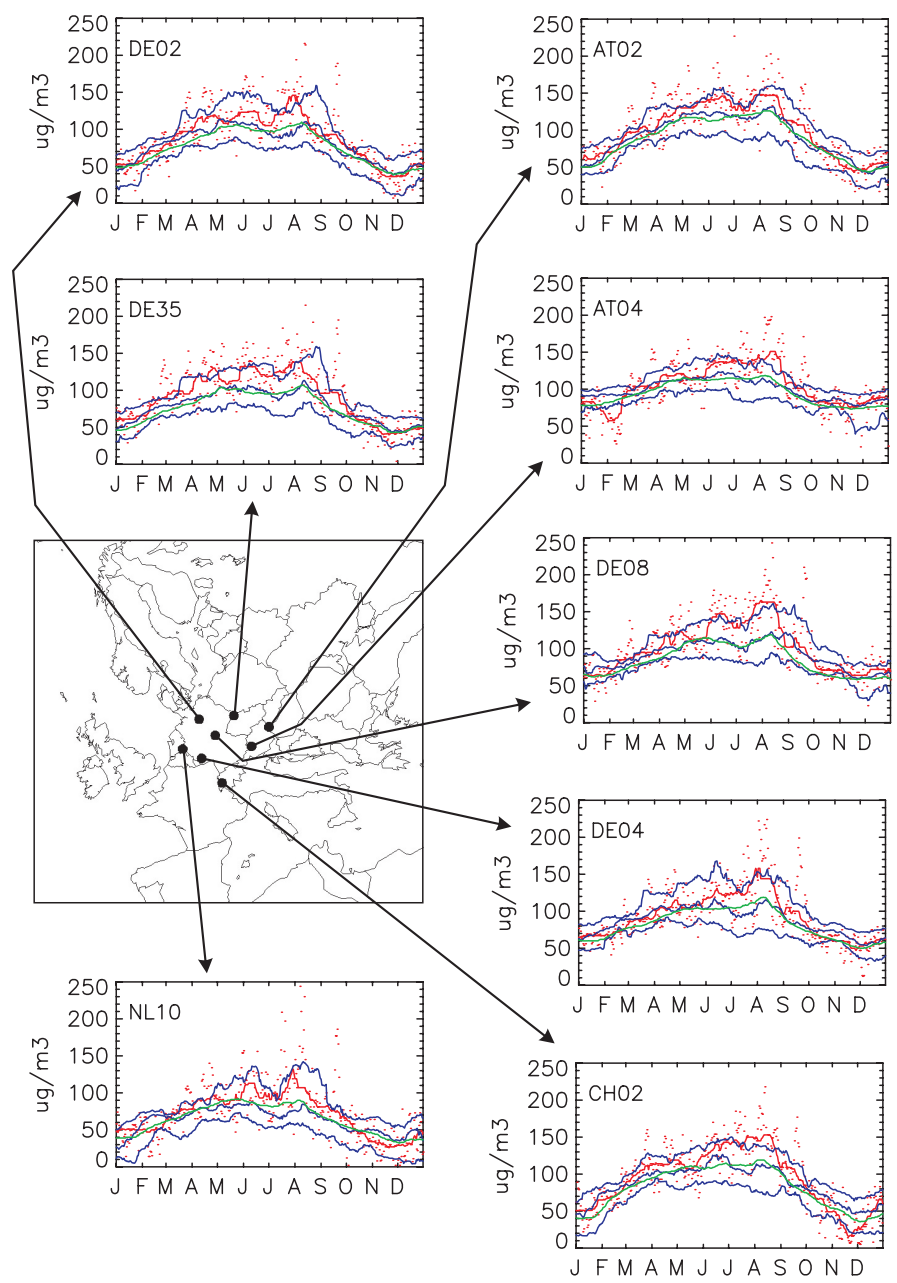

\section{ACPD}

5, 9003-9038, 2005

Ozone in Europe 2003

\section{S. Solberg et al.}

Title Page

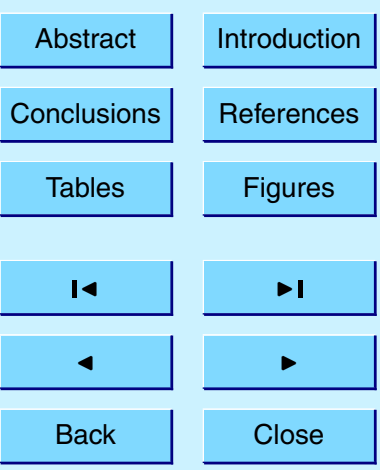

Full Screen / Esc

Print Version

Interactive Discussion

EGU

Fig. 5. Same as Fig. 4 for ozone monitoring sites in central Europe. 

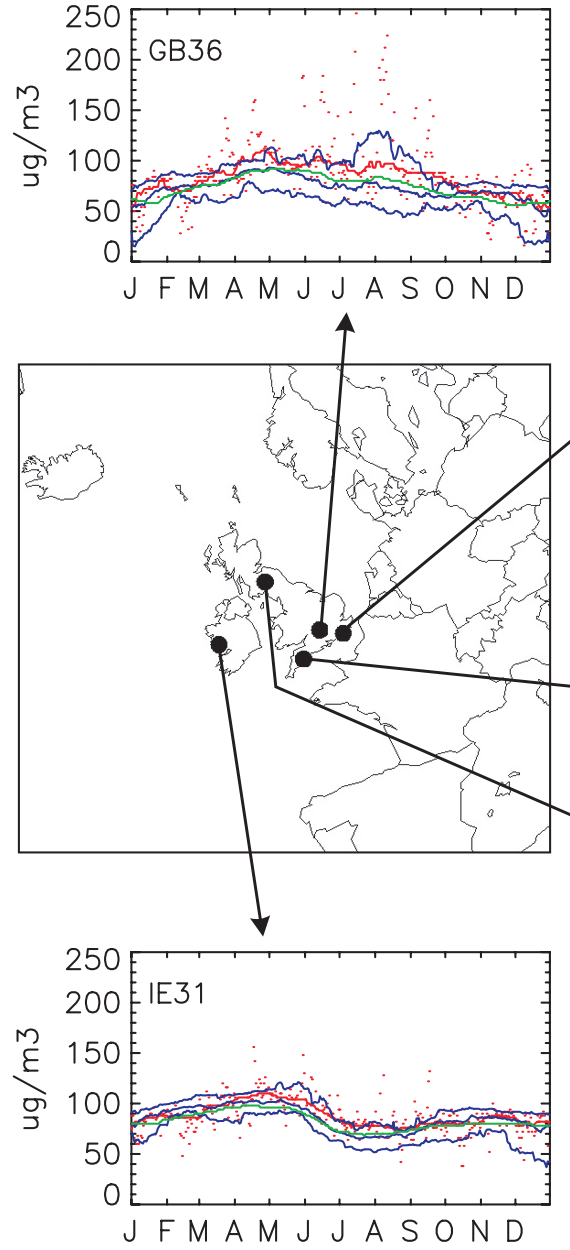

ACPD

5, 9003-9038, 2005

Ozone in Europe 2003

S. Solberg et al.

Title Page

\begin{tabular}{c|c} 
Abstract & Introduction \\
\cline { 1 - 1 } Conclusions & References \\
\cline { 1 - 2 } Tables & Figures \\
\hline
\end{tabular}

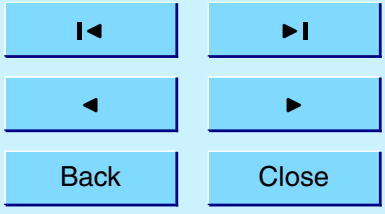

Full Screen / Esc

Print Version

Interactive Discussion

EGU

Fig. 6. Same as Fig. 4 for ozone monitoring sites in the UK and Ireland. 


\section{ACPD}

5, 9003-9038, 2005

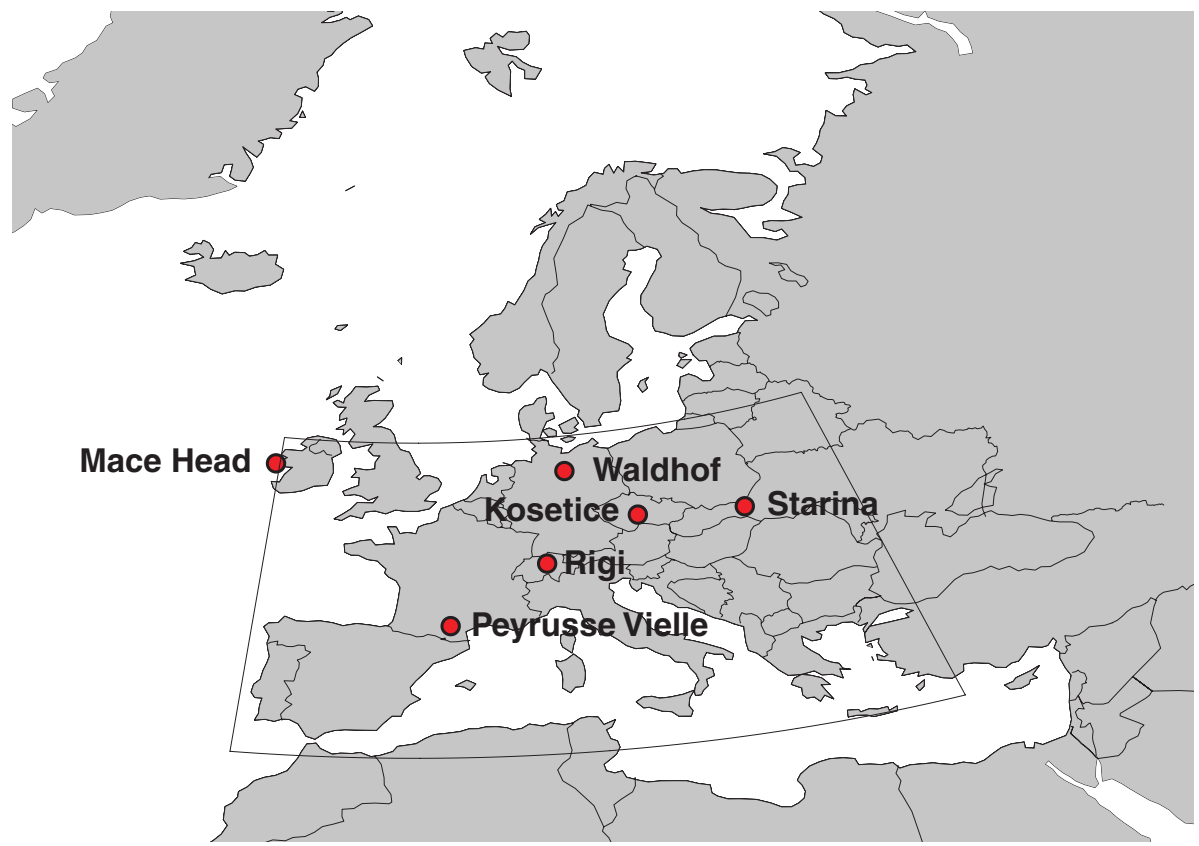

Ozone in Europe 2003

S. Solberg et al.

\begin{tabular}{|c|c|}
\hline \multicolumn{2}{|c|}{ Title Page } \\
\hline Abstract & Introduction \\
\hline Conclusions & References \\
\hline Tables & Figures \\
\hline
\end{tabular}

Fig. 7. Monitoring sites used for calculating air mass back trajectories. The region marks the domain defining the European residence times.

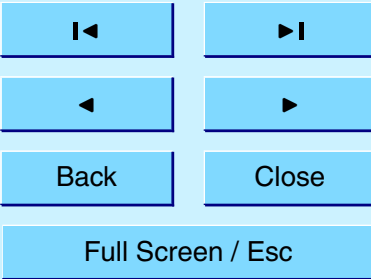

Print Version

Interactive Discussion

EGU 

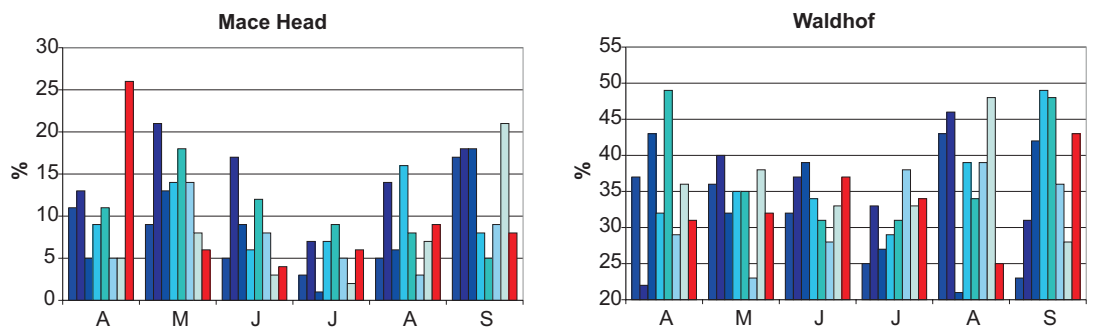

ACPD
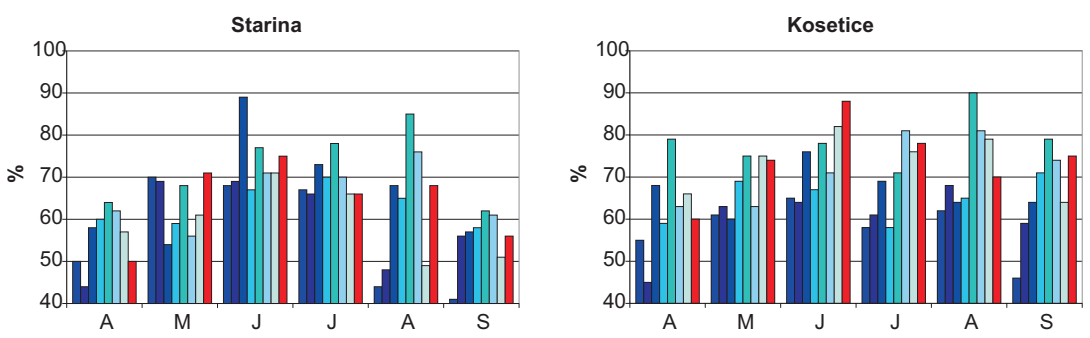

Title Page
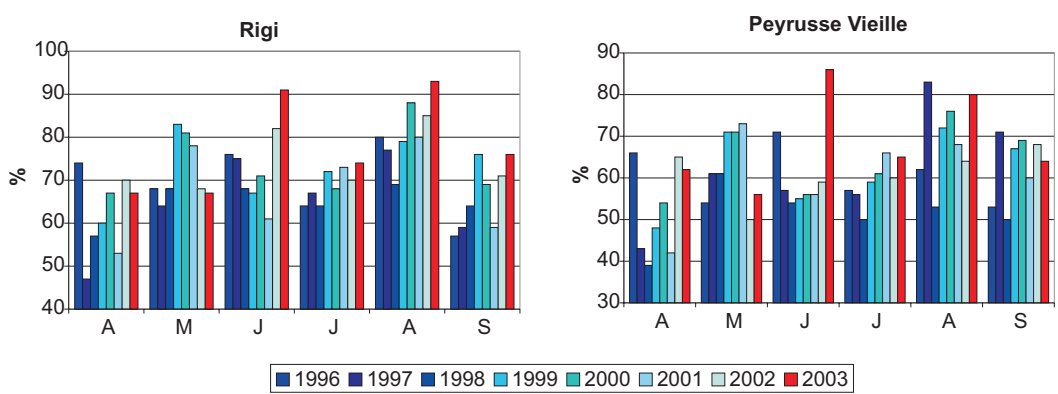

5, 9003-9038, 2005

Ozone in Europe 2003

S. Solberg et al.

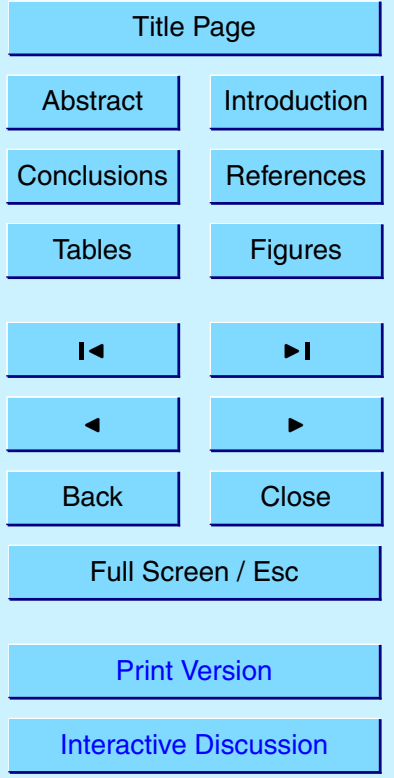

Fig. 8. The percentage residence time inside the European planetary boundary for air masses arriving at six sites given as monthly averages (April-September) during 1996-2003. The data are based on 7 days FLEXTRA 3-D back trajectories. Note that the scales on the y-axis varies.

EGU 


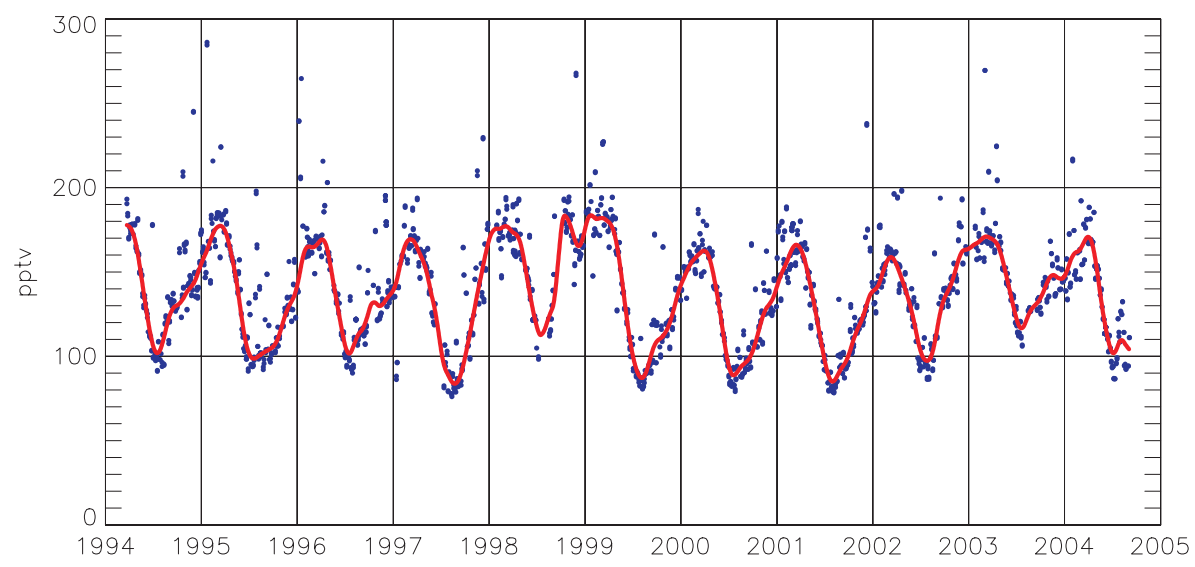

ACPD

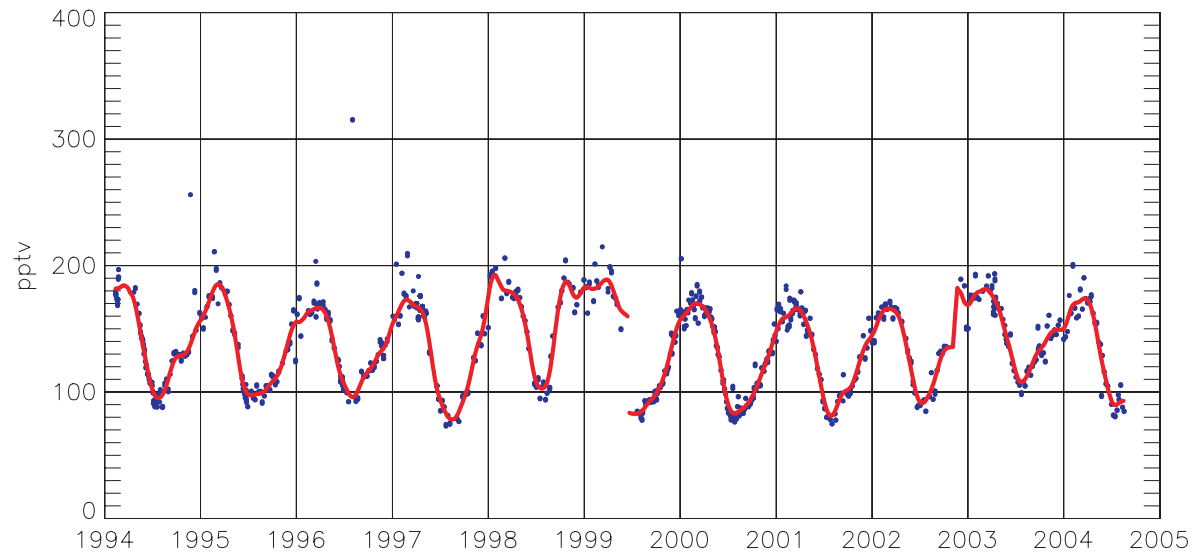

5, 9003-9038, 2005

Ozone in Europe 2003

S. Solberg et al.

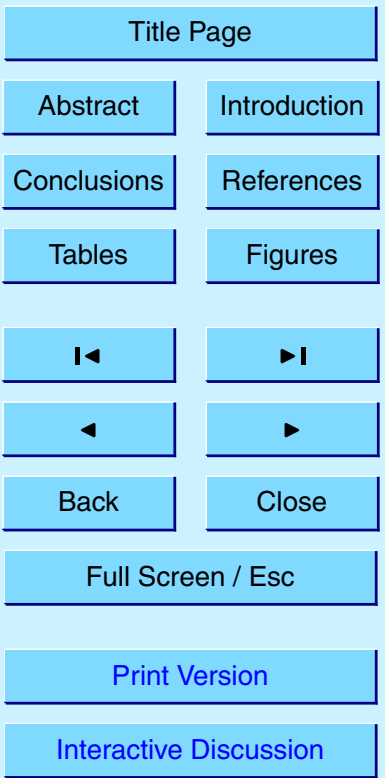

Fig. 9. Weekly flask samples of $\mathrm{CO}$ at Weathership M (top), and at Ny-Ålesund, Spitsbergen (bottom), during 1994-2004 (blue marks) and the corresponding smoothed 30-days' running average concentration (red curve). Data by courtesy of NOAA CMDL.

EGU 


\section{ACPD}

5, 9003-9038, 2005

Ozone in Europe 2003

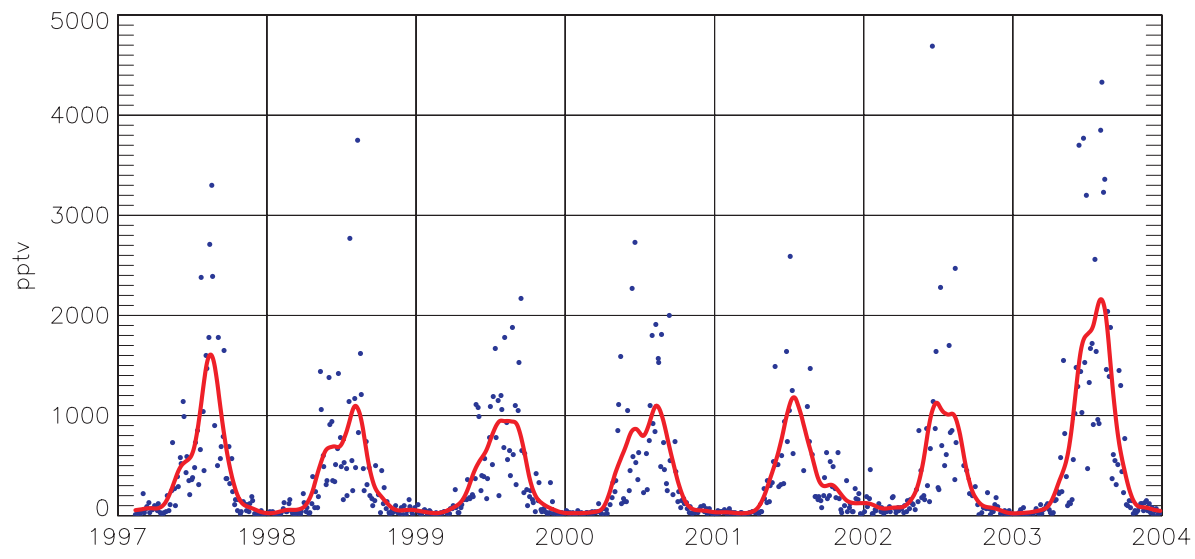

Fig. 10. EMEP canister samples of isoprene at Donon during 1997-2003. Individual samples (twice a week) are shown as blue marks and the corresponding smoothed running average as a red curve.
S. Solberg et al.

\begin{tabular}{|c|c|}
\hline \multicolumn{2}{|c|}{ Title Page } \\
\hline Abstract & Introduction \\
\hline Conclusions & References \\
\hline Tables & Figures \\
\hline 14 & $\rightarrow 1$ \\
\hline 4 & - \\
\hline Back & Close \\
\hline \multicolumn{2}{|c|}{ Full Screen / Esc } \\
\hline Print & rsion \\
\hline
\end{tabular}




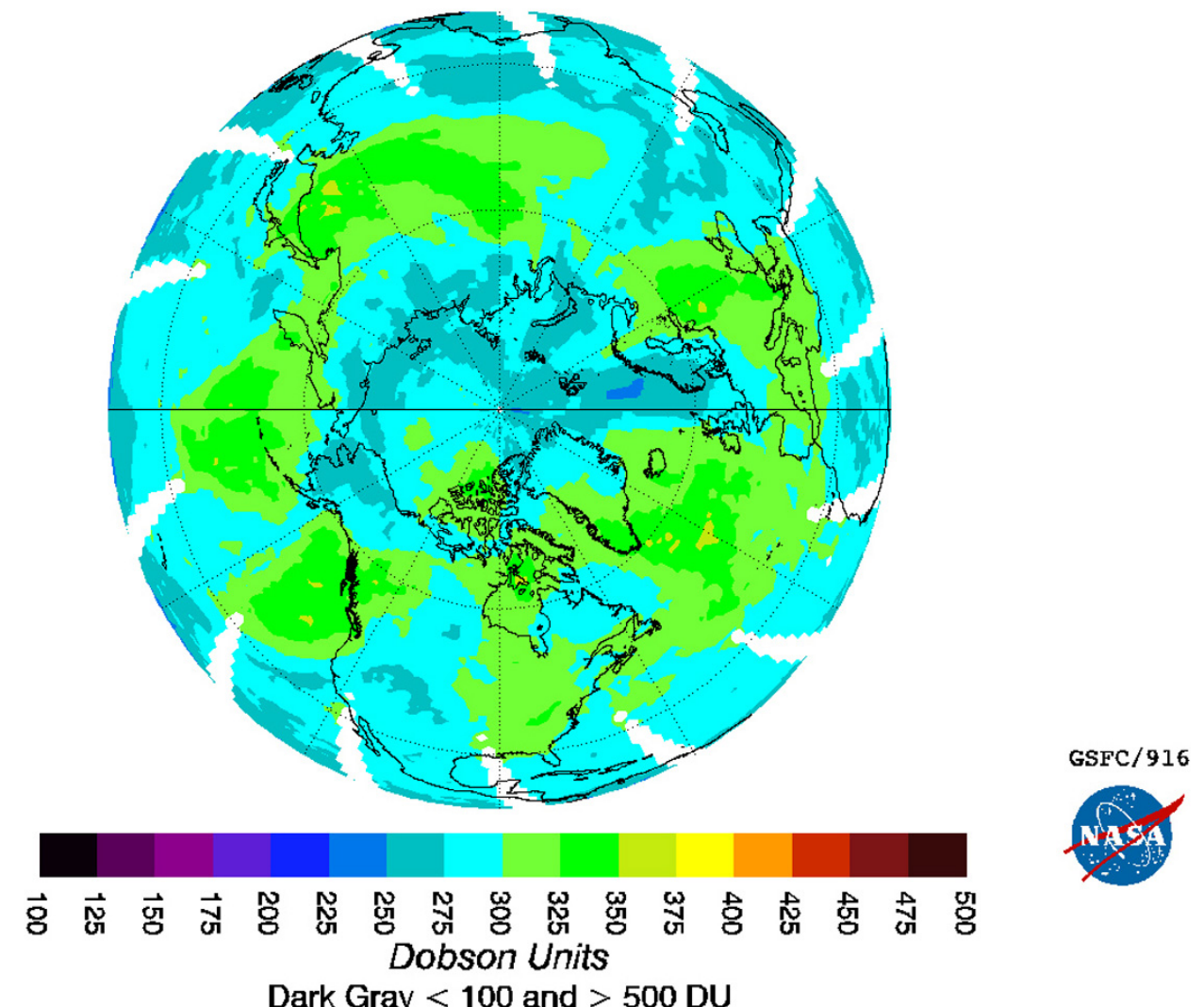

5, 9003-9038, 2005

\section{Ozone in Europe 2003}

S. Solberg et al.

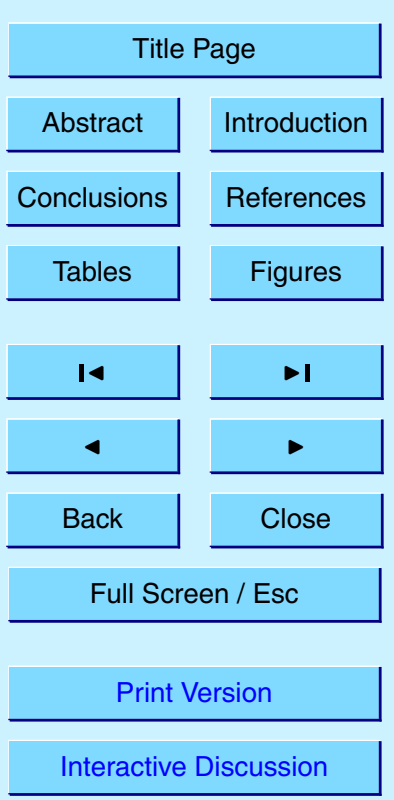

Fig. 11. Total column ozone map from TOMS Earth Probe on 10 August 2003. Image courtesy EGU of the Ozone Processing Team at NASA/GSFC. 


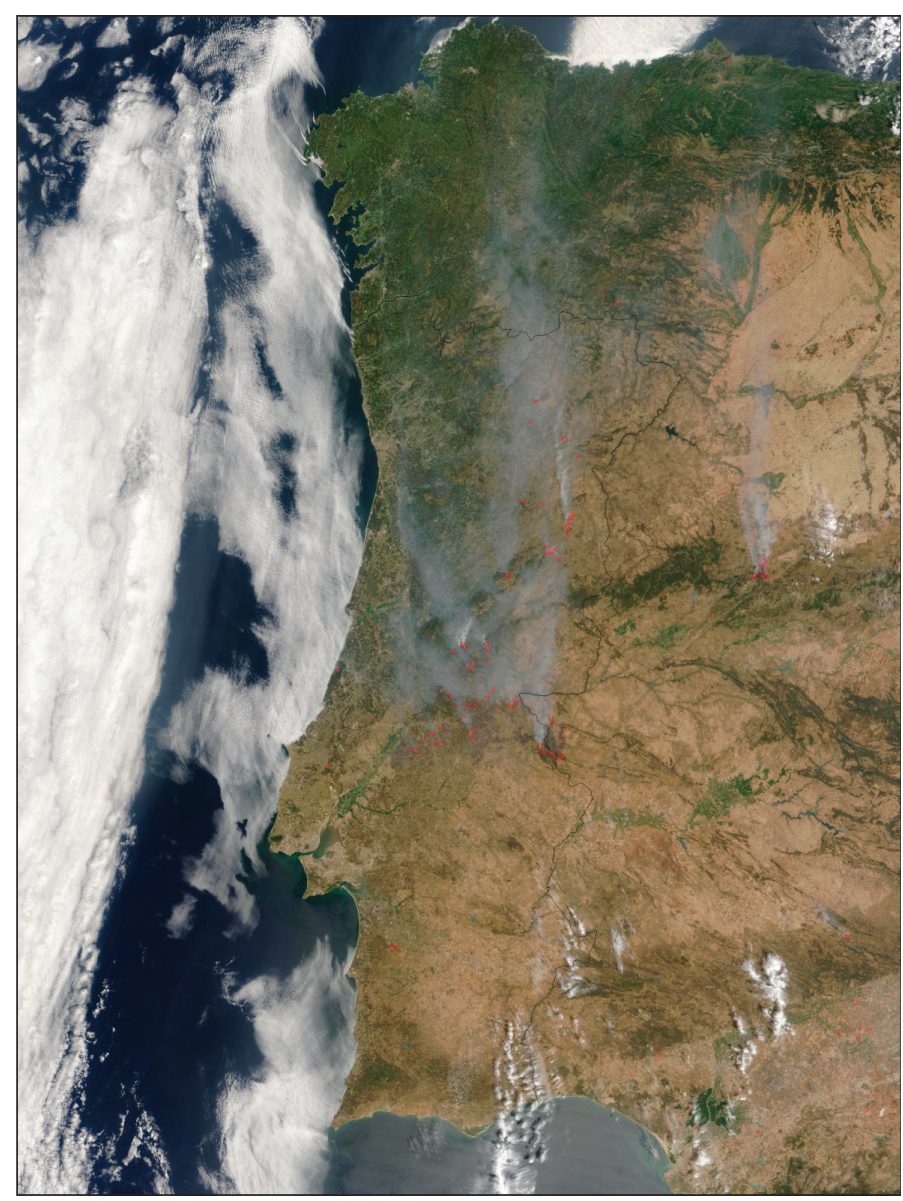

ACPD

5, 9003-9038, 2005

Ozone in Europe 2003

S. Solberg et al.

Title Page

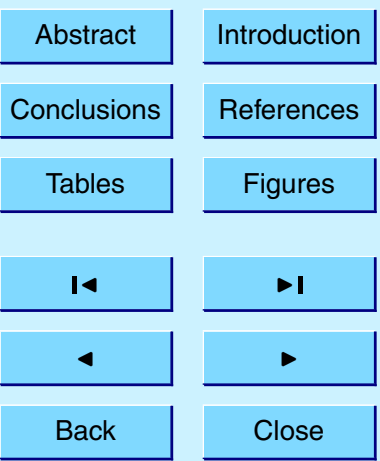

Full Screen / Esc

Print Version

Interactive Discussion

EGU

Fig. 12. Picture from the Terra satellite 4 August 2003 11:30 UTC showing extensive fires (marked with red symbols) and smoke plumes moving north on the western part of the Iberian Peninsula. Image courtesy of MODIS Rapid Response Project at NASA/GSFC. 


\section{ACPD}

5, 9003-9038, 2005

Ozone in Europe 2003
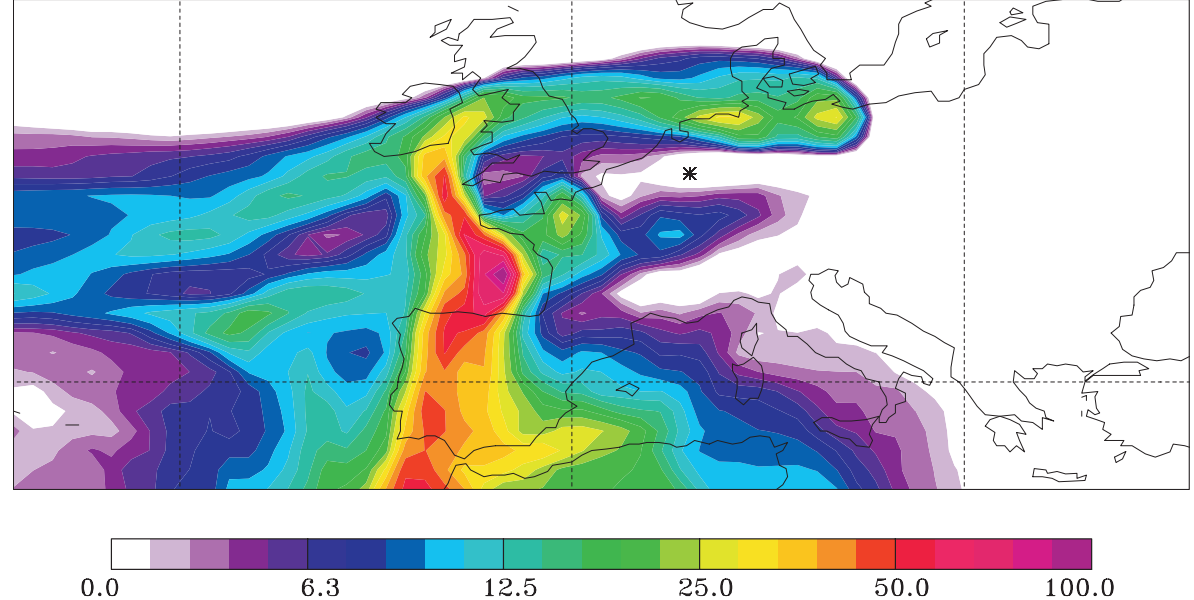

12.5

50.0

Fig. 13. Total columns of the response function to emission input (indicative of the residence time) over the last 3 to 20 days of all particles arriving at Eupen on 7 August between 00:00 UTC and 06:00 UTC on a $1^{\circ} \times 1^{\circ}$ grid as calculated with FLEXPART. The residence times are given in relative units of the maximum residence time below the panel.
S. Solberg et al.

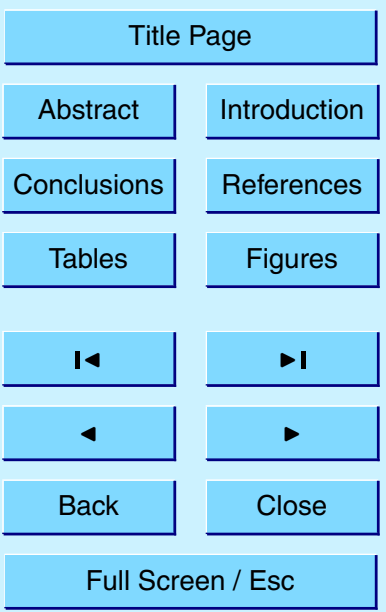

Print Version

Interactive Discussion 